Pacific Northwest

National Laboratory

Operated by Battelle for the

U.S. Department of Energy

\title{
Benson Beach Demonstration Project: Composition and Abundance of Biota at Three Alternative Sump Sites
}

\author{
G. D. Williams \\ W. H. Pearson \\ N. R. Evans \\ M. G. Anderson
}

January 2004

Prepared for the U.S. Department of Energy under Contract DE-AC06-76RL01830 


\title{
DISCLAIMER
}

This report was prepared as an account of work sponsored by an agency of the United States Government. Neither the United States Government nor any agency thereof, nor Battelle Memorial Institute, nor any of their employees, makes any warranty, express or implied, or assumes any legal liability or responsibility for the accuracy, completeness, or usefulness of any information, apparatus, product, or process disclosed, or represents that its use would not infringe privately owned rights. Reference herein to any specific commercial product, process, or service by trade name, trademark, manufacturer, or otherwise does not necessarily constitute or imply its endorsement, recommendation, or favoring by the United States Government or any agency thereof, or Battelle Memorial Institute. The views and opinions of authors expressed herein do not necessarily state or reflect those of the United States Government or any agency thereof.

\author{
PACIFIC NORTHWEST NATIONAL LABORATORY \\ operated by \\ BATTELLE \\ for the \\ UNITED STATES DEPARTMENT OF ENERGY \\ under Contract DE-AC06-76RL01830 \\ Printed in the United States of America \\ Available to DOE and DOE contractors from the \\ Office of Scientific and Technical Information, \\ P.O. Box 62, Oak Ridge, TN 37831-0062; \\ ph: (865) 576-8401 \\ fax: (865) 576-5728 \\ email: reports@adonis.osti.gov
}

\begin{abstract}
Available to the public from the National Technical Information Service, U.S. Department of Commerce, 5285 Port Royal Rd., Springfield, VA 22161 ph: (800) 553-6847$$
\text { fax: (703) 605-6900 }
$$

email: orders@ntis.fedworld.gov

online ordering: http://www.ntis.gov/ordering.htm
\end{abstract}

This document was printed on recycled paper. 
PNNL-14522

\title{
Benson Beach Demonstration Project: Composition and Abundance of Biota at Three Alternative Sump Sites
}

\author{
G. D. Williams \\ W. H. Pearson \\ N. R. Evans \\ M. G. Anderson \\ Marine Sciences Laboratory \\ Sequim, Washington
}

January 2004

Prepared for

the Portland District of the

U.S. Army Corps of Engineers

under a Related Services Agreement

with the U.S. Department of Energy

Contract DE-AC06-76RL0 1830

Pacific Northwest National Laboratory

Richland, Washington 


\section{Executive Summary}

The Portland District of the U.S. Army Corps of Engineers is investigating plans to provide sediment to nourish beaches north of the Mouth of the Columbia River (MCR). Under the currently designed proposal, sediment dredged from the MCR will be temporarily stored at one of three proposed areas south of the North Jetty before being redredged and moved by a cutterhead pipeline dredge over the jetty to nourish Benson Beach. Resulting potential impacts to resident Dungeness crab (Cancer magister) and fishes represent one of the criteria for evaluating each of the alternative locations. To establish the species composition and relative abundance of crabs and fishes associated with each of the three proposed sump areas, researchers from the Pacific Northwest National Laboratory, Marine Sciences Division completed nine field sampling trips from July 8, 2003, to November 1, 2003, for a total of 113 successful trawls comprising an area of over 7.4 ha $\left(74,156 \mathrm{~m}^{2}\right)$. This report documents the results of that effort.

Dungeness crab were present in each of the alternative sump areas, with significantly higher total crab densities detected in Area 1 as compared with Area 2. Soft-shell crab were not abundant in any area. A high statistical power indicated a strong likelihood of detecting significant differences with the given sampling effort. Over time, total crab densities generally increased, with a sharp jump in mid-September associated with an influx of Age 1+ crab. In general, Age 2+ crab predominated through early September. Young of the year (YOY) and Age 3+ crab composed a fairly small proportion of the overall catch.

Over 11,500 individual fishes, representing at least 26 major taxa, were collected over the course of the sampling period, including numerically dominant Pacific tomcod (Microgadus proximus), whitebait smelt (Allosmerus elongatus), Northern anchovy (Engraulis mordax), staghorn sculpin (Leptocottus armatus), and English sole (Pleuronectes vetulus). Fish species composition and relative abundance were similar between each of the sump areas. No ESA-listed fish species were collected in any trawl.

With regard to physical properties, Area 1 was significantly shallower than either Area 2 or Area 3, although surface and bottom temperature and salinity generally were indistinguishable between each of the study areas. Bottom temperatures increased an average of $4^{\circ} \mathrm{C}$ in late September.

Age composition and density of crab from sump alternative areas differed from previous investigations conducted in the Columbia River Estuary, which documented that associated crab populations were predominantly composed of YOY crab entering the estuary from the ocean. These differences may be attributed in part to differences in sampling gear, interannual variability in crab populations or movement, and the spatial distribution of sampling stations.

Size frequency analysis suggests that the seasonal pulses of Age 1+ crab may represent two subpopulations, smaller sized nearshore and larger estuarine crabs that seasonally mix in the MCR. However, the value of the sump areas as a migratory corridor or an overwintering area is unclear. Questions still remain about the environmental cues for the onset of these movements.

To understand the relative risk of losses to crab populations associated with dredging impacts at the sump alternative areas, it is recommended that a modified dredge impact model be developed using the data collected in this study. This model should estimate crab adult equivalent loss and associated error rates to gain a population-level perspective on the potential entrainment impacts at each of the three alternative sump areas. As well, a sustained survey of Dungeness crab distribution and movement within the Columbia River estuary would clarify the relative habitat value of the sump areas for crab populations, and support management decisions relative to issues associated with dredged material handling and disposal in the MCR. 


\section{Acknowledgements}

This study would not have been possible without the assistance of a number of individuals. We would like to gratefully acknowledge the contributions of field scientists that collected most of these data: Mike Anderson, Gary Dennis, Nathan Evans, and John Southard. Nathan Evans and Lee Miller provided GIS support post-processing field coordinates and creating maps. Mike Anderson did much of the data entry and QA/QC work. Valerie Cullinan conducted the statistics and assisted in their interpretation. We would also like to thank Marci Cooke of the Corps, who also accompanied us in the field on one occasion and provided invaluable assistance. This work was supported by the USACE Portland District. Mr. Kim Larson was the Corps Technical Representative. Ms. Doris McKillip was the Corps Project Manager for the MCR Dredging Project. 


\section{Acronyms}

$\begin{array}{ll}\text { AEL } & \text { adult equivalent loss } \\ \text { ANOVA } & \text { analysis of variance } \\ \text { CI } & \text { confidence interval } \\ \text { Corps } & \text { U.S. Army Corps of Engineers } \\ \text { CW } & \text { carapace width } \\ \text { DIM } & \text { Dredge Impact Model } \\ \text { GLIM } & \text { generalized linear model } \\ \text { GPS } & \text { global positioning system } \\ \text { MCR } & \text { Mouth of the Columbia River } \\ \text { MSL } & \text { Marine Sciences Laboratory } \\ \text { SAFE } & \text { surrounded around floatation equipped } \\ \text { TL } & \text { total length } \\ \text { WDFW } & \text { Washington Department of Fish and Wildlife } \\ \text { YOY } & \text { young of the year }\end{array}$




\section{Contents}

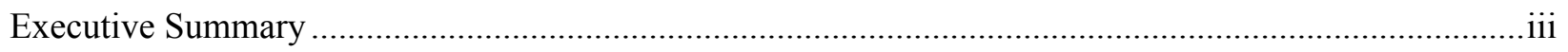

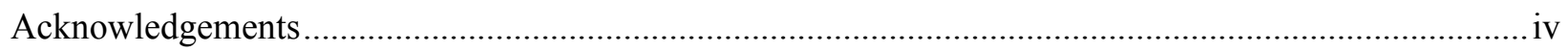

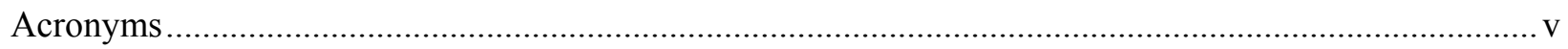

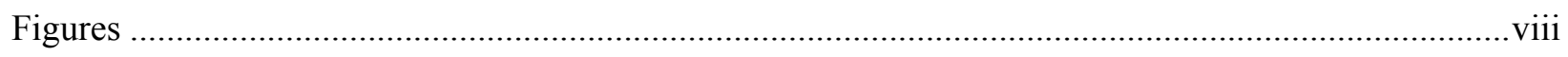

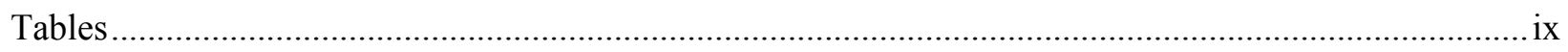

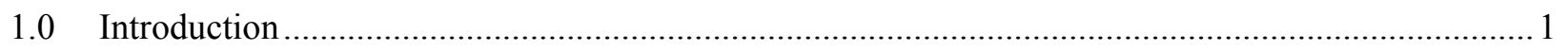

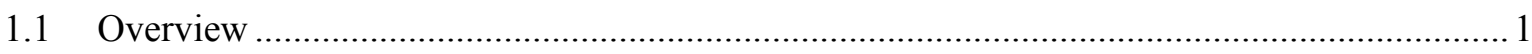

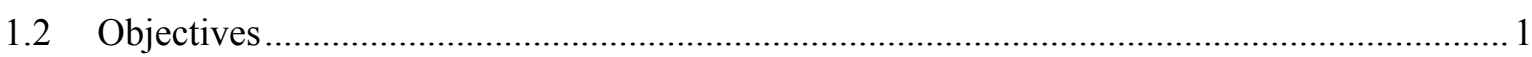

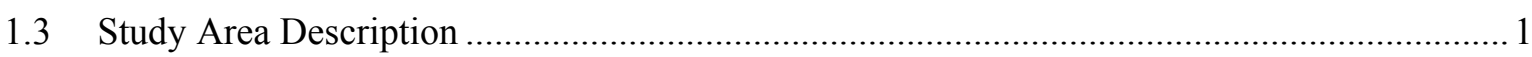

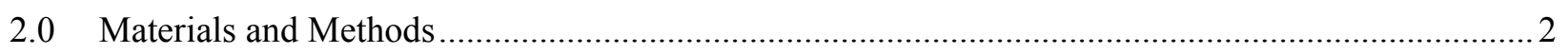

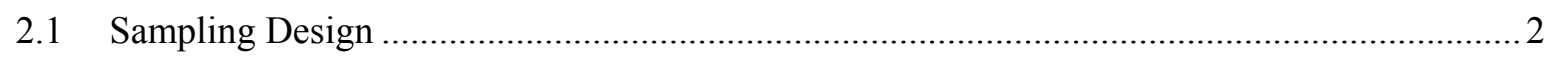

2.2 Methods for Crab and Fish Density Measurements ............................................................2

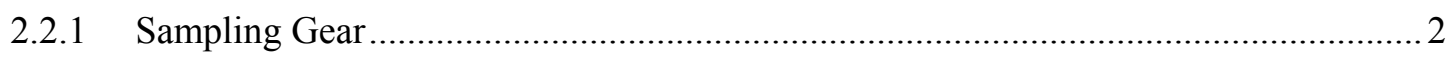

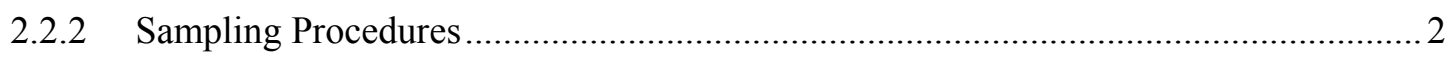

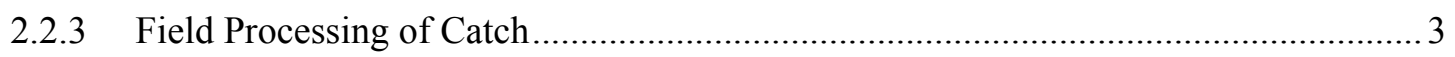

2.2.4 Calculating Sample Area and Catch Densities ...................................................... 3

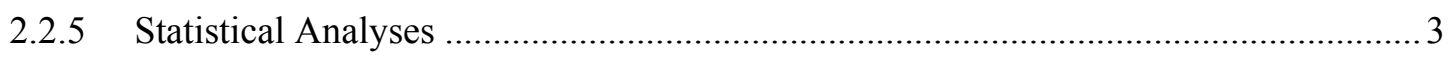

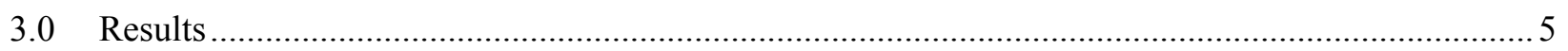

3.1 Site Characteristics and Accomplished Sampling ............................................................ 5

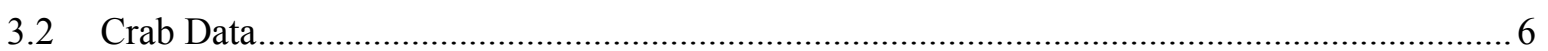

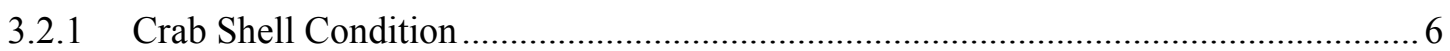

3.2.2 General Trends in Crab Density Among Sump Areas Over Time .............................. 6

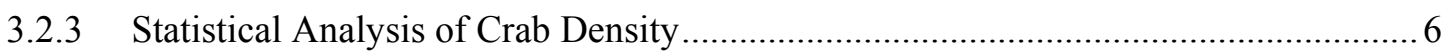

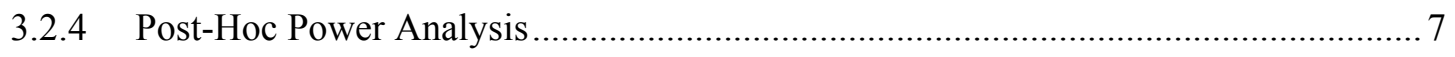

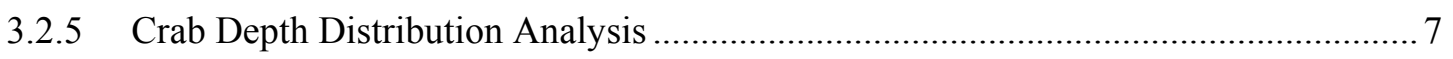

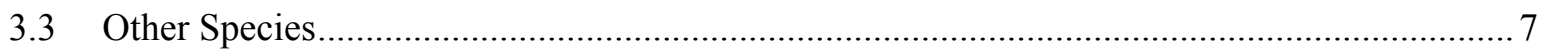

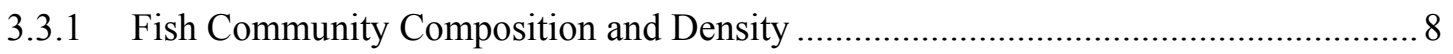

3.4 Physical Properties: Depth, Water Temperature, and Salinity ........................................... 8

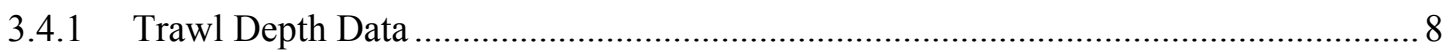

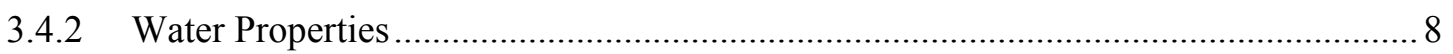

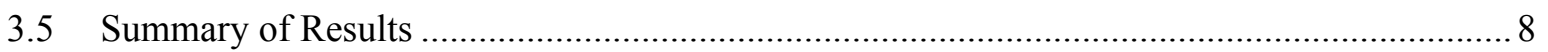

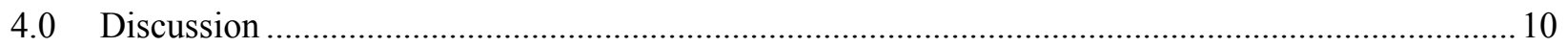




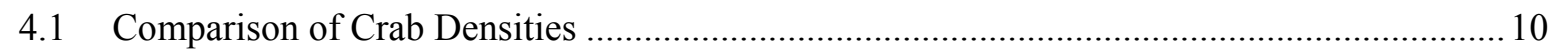

4.2 Differences in Crab Densities among Sump Areas ......................................................... 11

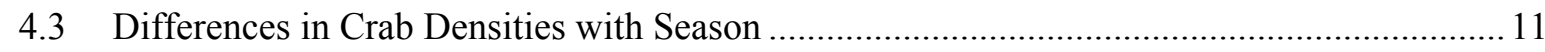

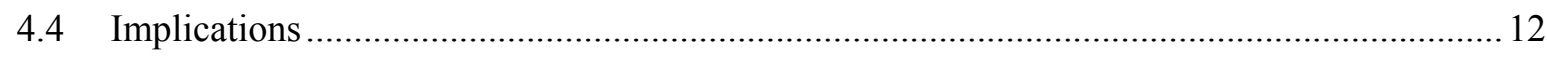

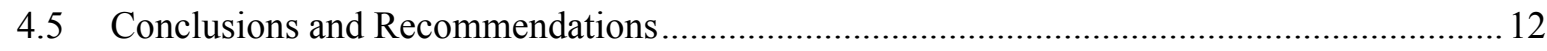

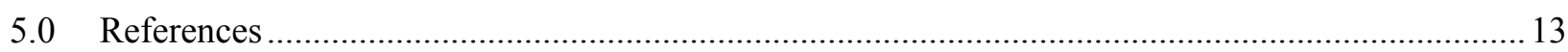

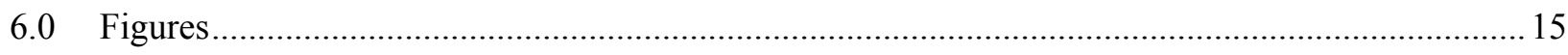

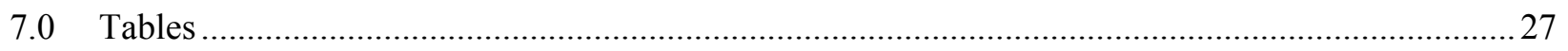

Appendix A: Length Frequency Graphs of Most Abundant Fish Species .............................................. 32 


\section{Figures}

Figure 1. Map of the Study Area, Including the Three Sump Alternative Sites and North Jetty Dredged Material Disposal Site

Figure 2. Mean Water Depth (ft) Measured During Trawl Sampling at Each Sump Alternative Area.. 16

Figure 3. Trawl Sampling Effort, Color Coded by Sampling Date ..................................................... 16

Figure 4. Dungeness Crab Densities Averaged over Entire Sampling Period ( $\pm 95 \%$ Confidence

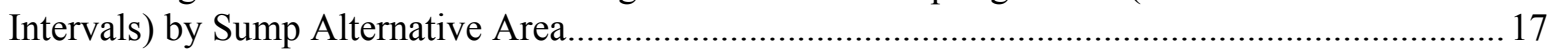

Figure 5. Trawl Sampling Effort, Color Coded by Relative Density of Total Crab in Trawl.................... 17

Figure 6. Dungeness Crab Densities (by Sex and Age Class) Averaged Over Entire Sampling Period

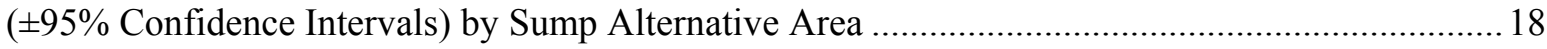

Figure 7. Density of Dungeness Crab Averaged Over All Areas (+/- 95\% Confidence Intervals) by

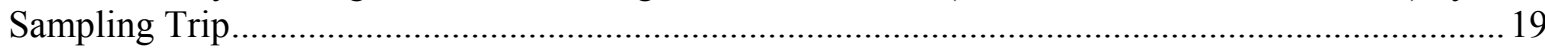

Figure 8. Dungeness Crab Densities (by Sex and Age Class) by Sampling Trip ( $\pm 95 \%$ Confidence

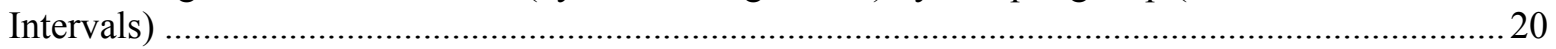

Figure 9. Interaction Plots of Mean Densities of YOY Unsexed (US), Male (M), and Female (F)

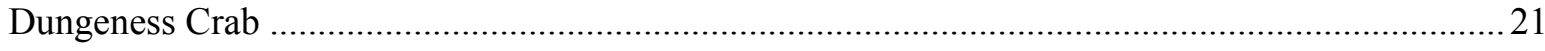

Figure 10. Interaction Plots of Male (M) and Female (F) Age 1+ (1P), 2+ (2P), and 3+ (3P) Dungeness Crab Mean Densities.

Figure 11. Interaction Plots of Total Male (TotM), Total Female (TotF), and All (Total-C) Dungeness

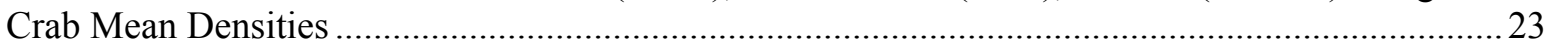

Figure 12. Mean Density of Numerically Dominant Fish Species Over Time .......................................24

Figure 13. Mean Surface and Bottom Water Salinity ( $\pm 95 \%$ Confidence Intervals) at Each Study Area

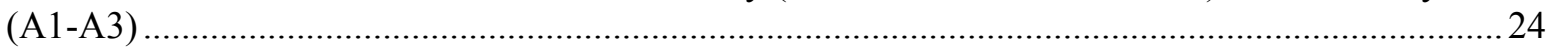

Figure 14. Mean Surface and Bottom Water Temperature ( $\pm 95 \%$ Confidence Intervals) at Each Study Area (A1-A3).....

Figure 15. Generalized Movements of Juvenile Dungeness Crab to and from Grays Harbor and the Nearshore Environment (from Armstrong et al. 1987)

Figure 16. Size Frequency Distribution of Dungeness Crab Collected at all Sump Areas from July through Early November 2003 (carapace width in $\mathrm{mm}$ ) .26 


\section{Tables}

1. Coordinates of Proposed Alternative Sump Areas and Existing North Jetty Disposal Site.

Projection is Oregon State Plane North Zone, NAD 27 Datum, Units in ft.

2. Trip Dates and Corresponding Sampling Weeks, Indicating Neap and Spring Tide Series.

3. Trawl Depth (ft) Summary Statistics Associated With Each Sump Alternative Area ......................28

4. Soft-Shell Crab (Numbers) Collected Over the Course of the Study Period ....................................28

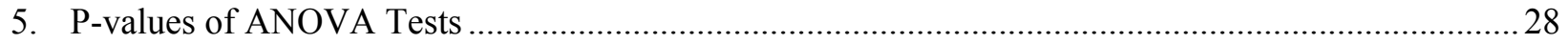

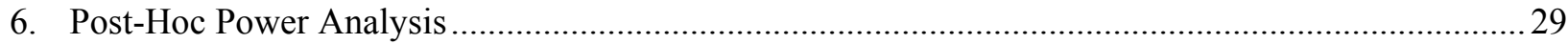

7. Fish Taxa in Rank Order of Abundance, Including Mean Density (Fish/ha), Mean Size ( $\mathrm{TL}=$ Total Length in $\mathrm{mm}$ ), and Size Range.

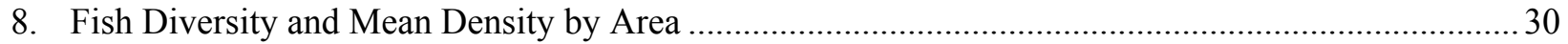

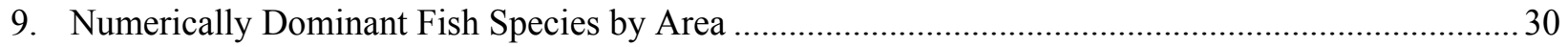

10. Annual Variability of Mean 1+ Crab Densities (crab/ha) from All Habitats in Four West Coast Estuaries (Rooper et al., 2002) 


\subsection{Introduction}

\subsection{Overview}

There is a need to provide sediment to nourish Benson Beach, the public beach north of the North Jetty in the Mouth of the Columbia River (MCR). The Portland District of the U.S. Army Corps of Engineers (Corps) is currently considering alternative scenarios for the location, alignment, and basic dimensions of the North Jetty sump area for rehandling dredged materials from the MCR. Under the currently designed proposal, sediment dredged by hopper dredges from the MCR will be temporarily stored at one of three proposed areas south of the North Jetty, before being redredged and moved by a cutterhead pipeline dredge over the jetty to nourish Benson Beach (Figure 1).

Potential impacts to resident Dungeness crab (Cancer magister) and fishes associated with the dredged material rehandling area represent one of the criteria for evaluating each of the alternative locations. Previous studies have suggested that Dungeness crab densities are relatively high within this region of the MCR, especially for early instar (age 0+) crab during the late summer (McCabe et al., 1986; McCabe and McConnell 1989). Prior to the study described here, there were no crab and fish density data specific to the three proposed sump areas.

\subsection{Objectives}

The primary objective of the study was to establish the species composition and relative abundance of macrobiota associated with each of the three proposed sump areas. To accomplish this objective, information was collected on the density, age class, sex, and condition factors of crab in each of these areas over the proposed period of performance (twice monthly from July through November 2003). Information on the species composition, density, and size of fishes and other organisms was also gathered and summarized.

\subsection{Study Area Description}

Table 1 provides coordinates for the outside corners of each proposed sump area alternative, as well as the North Jetty disposal site currently used by the Corps. Each of the three dredge sump areas measures approximately $2000 \mathrm{ft}$ by $1000 \mathrm{ft}$ and encompasses approximately $18.6 \mathrm{ha}$ (Figure 1). Because of some overlap between areas, the total combined area of the three proposed sump area alternatives encompasses 44.8 ha. 


\subsection{Materials and Methods}

\subsection{Sampling Design}

Sampling design challenges were presented by the physical dynamics of the MCR, combined with uncertainty associated with the ecological dynamics of local Dungeness crab populations. Because tidal and lunar cycles can mediate salinity regimes and influence crab behavior (Pearson et al., 2003), sampling was consistently conducted (with one exception) during neap tides when salinity has the greatest penetration into the estuary. Likewise, sampling was designed to be conducted over a protracted time period to capture seasonal life history events that may affect crab distribution and abundance (e.g., movement of Age 1+ crab out of the estuary in the fall, as observed in Grays Harbor by Armstrong et al., 1987).

To encompass the entire area covered by the three proposed alternative sump areas, five equally spaced transects were pre-established (coded A-E) in each area and marked with global positioning system (GPS) coordinates to guide trawl samples. Transect sampling was stratified by area and sampled randomly over two trips per month during neap tide series from July 8 to November 1, 2003.

\subsection{Methods for Crab and Fish Density Measurements}

\subsubsection{Sampling Gear}

A 3-m plumb staff beam trawl was used to quantitatively collect crab, fish, and other invertebrate taxa in each sump area. This gear is the recommended method for sampling nearshore subtidal soft-bottom habitats in Puget Sound and coastal estuaries (Gunderson and Ellis 1986; Armstrong et al., 1987; Gunderson et al., 1990; Miller et al., 1990; Simenstad et al., 1991). The trawl net design incorporates a net body composed of 14-mm mesh, a 5.5-mm mesh-lined cod-end, and a double strand of "tickler" chains on the ground rope. The beam holds the effective net opening at a constant width of $2.3 \mathrm{~m}$, as compared with most conventional otter trawls in which the net opening can be distorted under different conditions. The "tickler chain" on the ground rope increases the capture efficiency of crabs and flatfish; tom-weights are used to keep the trawl on the bottom. It has been acknowledged that efficiency may be low for larger size classes of fishes and may also vary over different bottom substrates.

\subsubsection{Sampling Procedures}

Sampling was undertaken twice a month, weather permitting, from July 8, 2003, to November 1, 2003 (nine sampling periods). A minimum of three (five, if possible) replicate samples were taken in each sump area on each sampling period over a period of 2 to 3 days. Trawling was conducted during low amplitude neap tide series, during the windows of slack tide or low tidal flow, and generally in the morning. Viable periods were largely determined by weather and tide windows when trawling was feasible, due to currents, prevailing winds, and waves. Between three to nine samples were collected each day.

During each sample, the beam trawl net was towed over a fixed distance by the Marine Sciences Laboratory (MSL) research vessel (21-ft surrounded around floatation equipped [SAFE] boat) during relatively slack tides at the gear's recommended tow speed of 1.4 knots $(0.72 \mathrm{~m} / \mathrm{s})$ with a scope exceeding a 5:1 ratio (distance wire out:water depth). Trawls were conducted for a 6-minute duration, which allowed for samples to exceed the recommended standard tow distance of $215 \mathrm{~m}$ (Miller et al., 1990). 
GPS coordinates for each trawl (start and stop points) were collected in the field using the boat GPS unit and recorded on data sheets. Other relevant information noted on data sheets included date, start and end time, start and end depth, set number and location identification, scope, travel direction, speed over ground, sea state, wind speed and direction, and tide stage. Water properties (salinity and temperature) were also recorded at the water surface $(0.5 \mathrm{~m}$ depth) and near the bottom with a YSI model 556 multiple probe system after each trawl.

The presence of crab pots and fishing vessels presented some additional challenges to conducting sampling in this area adjacent to the North Jetty, and were noted in the field log. Trawl gear often became entangled in both commercial and recreational crab pots and lines (some not marked by buoys). These samples were discarded to account for potential impacts to trawl gear efficiency.

\subsubsection{Field Processing of Catch}

At the completion of each trawl, researchers sorted living organisms and identified and enumerated individuals from the following taxa: crab (C. magister and other species), shrimp (e.g., Crangon spp.), and all fish species. The relative abundance of other species (e.g., gastropods, bivalves, mysids, cnidaria) was noted, and the volume and type of substrate and vegetation in each trawl was recorded. The carapace widths $(\mathrm{CW})$ of all crab were measured with calipers or a measuring board to the nearest millimeter and assigned one of four age-class categories, as determined from Armstrong et al. (1987): young of the year (YOY) $(0 \mathrm{~mm}$ to $50 \mathrm{~mm})$; Age $1+(51 \mathrm{~mm}$ to $100 \mathrm{~mm})$; Age $2+(101 \mathrm{~mm}$ to $150 \mathrm{~mm})$; and Age 3+ (greater than $150 \mathrm{~mm}$ ). Larger crab were sexed, and shell hardness noted. Shell hardness was evaluated following the scale used by the Washington Department of Fish and Wildlife (WDFW), which provides three major stages (hard, intermediate, and soft), each with two or three subgrades of shell condition or hardness (Antrim and Gruendell 1998). Total length (length from the tip of the upper jaw to the end of the caudal fin) of fishes was also recorded. All animals were held onboard in tubs of seawater and rapidly returned to the channel.

Data were recorded on standard field data sheets printed on waterproof paper, and then entered in a computer database. All data sheets were completed and errors corrected with a single line that was initialed and dated. At the end of each sampling day, researchers reviewed the data sheets for completeness, accuracy, and legibility. Data were then entered into an electronic database in the laboratory, with final QA/QC check of the database made for data quality and accuracy.

\subsubsection{Calculating Sample Area and Catch Densities}

To calculate trawl lengths, field-collected GPS coordinates were loaded into ArcView and re-projected to the OR SPN 27 projection. The re-projected coordinates were used to build a line representing each trawl, which was then checked and labeled. The ArcView command "Shape.ReturnLength" was used on the resulting lines to estimate the length for each trawl.

Sample area associated with each trawl was estimated by calculating area swept $(2.3 \mathrm{~m}$ width * trawl length). Quantitative estimates of animal density were derived by dividing catch totals by area swept (e.g., crab per hectare $=$ total $\#$ crab / area swept in $\mathrm{m} * 10,000 \mathrm{~m} / \mathrm{ha}$ ). Separate density estimates were also calculated for each trawl sample by crab age class and sex.

\subsubsection{Statistical Analyses}

Analysis of variance (ANOVA), employing generalized linear models (GLIM) for unbalanced designs, was used to explore differences in crab density for the main effects and interaction of area and time. Both 
Area (three levels: Area 1, Area 2, and Area 3) and Week (nine levels: Weeks 0, 2, 4, 6, 8, 10, 12, 16, and 17) were considered fixed factors in the model, with depth included in the analysis as a covariate. Separate analyses were conducted on densities of all (total) crab, total male and total female crab, as well as on each sex and age-class category (e.g., YOY males, YOY females, Age 1+ males, etc.). Tukey pairwise comparisons were used to examine significant differences between factor levels. The upper and lower $95 \%$ confidence limits of the difference in density between all possible pairs of areas were also calculated. Interaction and main effects plots were used to interpret differences. Residual plots were used to assess model assumptions.

A chi-square analysis was used to compare each area's age class by sex density distribution (summed over time and scaled by 1000). The 9 by 3 contingency table was used to test the null hypothesis that crab densities were proportionally distributed by age class and sex between areas. Histograms of changes in density through time by age class and sex were used to provide a visual interpretation of the differences in areas across time.

A post-hoc power analysis was conducted to examine the likelihood of detecting significant differences in crab densities between areas, given samples sizes of $n=37$ (minimum replication / area) and alpha $=$ 0.05. Separate analyses were conducted on total (both sexes), total female, and total male crab.

Additional analyses were used to explore whether trawl depth was related to crab abundance. A one-way ANOVA was used to test the null hypothesis that sampling depths in each area were equal. Regression analyses examined the relationship between trawl depth and total (both sexes), total female, and total male crab densities. 


\subsection{Results}

\subsection{Site Characteristics and Accomplished Sampling}

A total of nine sampling trips, each lasting from 3 to 4 field days, were conducted over a period of 17 weeks between July 8, 2003 and November 1, 2003 (Table 2). Weather conditions were generally favorable over the duration of the sampling period, although typical morning fog and afternoon winds periodically produced sampling delays. In general, the study area was characterized by complex tidal currents. Morning slack tides and the ensuing low exchange allowed approximately 4 to 6 hours of consistently low current speeds appropriate for sampling; slack tides occurred one hour before the predicted slack, although this varied with area.

Area 1, the innermost study site, was the most protected from wind, although currents here were the most variable. Wave reflection from the nearby bluff was high, and high crab-pot densities (average of 3 pots within $100 \mathrm{~m}$ of a transect line) caused the most aborted trawls as a result of entanglements. Sediment in this area appeared to be finer (muds) than in other areas and trawl samples often contained macroalgae (Enteromorpha and Ulva spp.). Water depths were also shallowest in Area 1, with an average trawl depth of $30.5 \mathrm{ft}$ (range: $26.3 \mathrm{ft}$ to $33 \mathrm{ft}$ ) (Figure 2, Table 3). Area 3, located midway between Areas 1 and 2, had fewer crab pots (less than $1 \mathrm{crab}$ pot within $100 \mathrm{~m}$ of transect line), more predictable tidal currents, and sandy sediment. Water depths in Area 3 were also intermediate to the other areas, with an average trawl depth of $33.4 \mathrm{ft}$ (range: $30.6 \mathrm{ft}$ to $36 \mathrm{ft}$ ). Area 2, the outermost (westernmost) study area, generally was devoid of crab pots and had sandy sediment, but was most exposed to wind and wave action. Strong currents in Area 2 created a strong rip that was apparent at the surface during tide shifts and rapidly diminished the effectiveness of any subsequent trawling efforts. Water was deepest in Area 2, with an average trawl depth of $38.4 \mathrm{ft}$ (range: $33.5 \mathrm{ft}$ to $41.9 \mathrm{ft}$ ).

Other notable events that influenced the sampling schedule included:

- August 21: Tuna seiners were anchored throughout the sampling area to take refuge from an offshore storm, causing a one-day sampling delay.

- September 17 - 18: The Corps dredge, Essayons, conducted dredged material disposal operations in the North Jetty dumpsite. Trawling efforts were periodically delayed to work around disposal events.

- October 2: Commercial salmon gillnetters were drift fishing throughout the sampling area. Trawling efforts were delayed or opportunistically moved to avoid these vessels and their nets.

- October 16 - 18: Sampling was aborted because of adverse weather conditions; trawl efforts were resumed during a weather window occurring over a spring tide series on October 25 - 26 (Table 2).

In total, 130 trawls were completed, 17 of which were aborted or discarded from the record because of entanglement with crab gear or poor efficiency due to currents. Of the 113 successful trawl samples, effort was distributed between alternative sump areas as follows: Areas 1 - 37, Areas 2 - 39, Areas 3 - 37 (Figure 3). Trawl lengths averaged $285 \mathrm{~m}$, with an average sampling area of $644 \mathrm{~m}^{2}$. Over the course of the study, an area of over 7.4 ha $\left(74,156 \mathrm{~m}^{2}\right)$ was sampled by the trawl gear. 


\subsection{Crab Data}

Over 4500 Dungeness crab were collected over the sampling period. Age 1+ crab composed the dominant $(71 \%)$ age class of the crab sampled, with males slightly more prevalent $(56 \%)$ than females (42\%). Subsequent sections further describe sex- and age-related density trends across the three sump areas over time.

\subsubsection{Crab Shell Condition}

The shell condition of most crab ( $>99 \%$ ) collected in the sump areas was classified as "hard" (stage one), based on a scale used by WDFW. A total of 15 stage-three soft-shell crab were collected over the course of sampling (Table 4). Most soft-shell crab were females $(66 \%)$ or age class $2+(73 \%)$. Soft-shell crab were distributed among the sump alternative areas as follows: Area 1 (7); Area 3 (5); Area 2 (3).

\subsubsection{General Trends in Crab Density Among Sump Areas Over Time}

The mean density of all crab (all sexes and age classes combined) in the three sump areas over the entire study period was $613 \mathrm{crab} / \mathrm{ha}$. Average total crab densities were highest in Area 1 at $769 \mathrm{crab} / \mathrm{ha}$, with 95\% confidence limits from 1001 to $536 \mathrm{crab} / \mathrm{ha}$, followed by Area 3 at $589 \mathrm{crab} / \mathrm{ha}$, with $95 \%$ confidence limits from 776 to $401 \mathrm{crab} / \mathrm{ha}$, and Area 2 at $455 \mathrm{crab} / \mathrm{ha}$, with $95 \%$ confidence limits from 641 to $268 \mathrm{crab} / \mathrm{ha}$ (Figure 4). These trends are also apparent spatially by examining the relative density of crab collected by individual trawl samples, with most "high-density" ( $>1000 \mathrm{crab} / \mathrm{ha}$ ) samples occurring in Areas 1 and 3 (Figure 5). The relative distribution of sex-ratios and age-classes, when averaged over time, was fairly comparable across the sump areas (Figure 6). In each of the three sump areas, Age 1+ crabs were most abundant, and sex ratios were skewed slightly in favor of males.

Over time, total crab densities generally increased, with a sharp jump in crab numbers in late September (trip 6) (Figure 7). Total crab density averaged less than $500 \mathrm{crab} /$ ha from July (trip 1) through early September (trip 5); thereafter (trips 6 through 9), crab densities remained greater than $500 \mathrm{crab} / \mathrm{ha}$. Sexratio and age-class data, examined separately for each sampling trip, show that an influx of Age $1+$ crab was largely responsible for most of these increases (Figure 8). In general, Age $2+$ crab predominated through early September, before relative abundance shifted to Age 1+ crab in all subsequent sampling efforts. Age 1+ sex ratios were notably skewed to males during late September and early October (trips 6 and 7), before shifting toward females in late October and early November (trips 8 and 9).

\subsubsection{Statistical Analysis of Crab Density}

A summary table of the ANOVA results is provided in Table 5. P-values provide guidance as to the significance of the factors (depth, area, time, and area * time interaction), with $\mathrm{p}<0.05$ indicating significant density differences at $\alpha=0.05$, and for our purposes $p<0.1$ suggesting a potential trend. In general, within the limited depth range present over the sump areas, trawl depth was not a factor affecting crab density (Table 5). Time (also described as sampling trip or week), was a major factor that influenced most of the analyses, resulting in significant time by area interactions when analyses were partitioned by age class and sex. For male crab, sampling time (week) was always a factor. For female crab, area often interacted with week. Finally, for total crab, area and week were each significant factors. Specific results are summarized below according to crab age class and sex.

For YOY crab, week interacted with area to affect density of female and unsexed (less than 30-mm CW) crab (Table 5). Multiple comparison tests show that female YOY crab densities were highest in early July, September (Areas 1 and 2), and late October (Areas 1 and 3) (Figure 9). Unsexed YOY crab density 
was highest in July (Area 3) and in early November (Areas 1 and 3). Week was a significant factor affecting YOY male crab density (Table 5), with highest densities in July, late September, and early November (all areas). Densities of YOY were among the lowest of all the age classes, averaging less than $32 \mathrm{crab} / \mathrm{ha}$.

For male Age 1+, 2+, and 3+ crab, week was always a factor affecting density (Table 5). In all areas, Age $1+$ male crab densities were significantly higher from mid-September to November, Age 2+ male crab densities declined after August, and Age 3+ male crab densities peaked in September (Figure 10). For female Age 1+, 2+, and 3+ crab, week always interacted with area to affect density (Table 5). Age 1+ female crab densities in Area 1 and Area 3 were significantly higher from late September to November, whereas Age 2+ and 3+ female densities peaked during August in Area 1 (Figure 10).

Week was always a factor influencing total male and total female crab densities, whereas both week and area significantly affected density of all crab, regardless of sex or age class (Table 5). Total female, total male, and all (both sex) crab densities in all areas were significantly higher from late September (week 10) to November (week 17) than in weeks before (Figure 11). As noted in section 3.2.2, these trends are undoubtedly affected by the high densities of Age 1+ crab observed throughout the study area during this time period. Total crab densities were significantly different $(p=0.041)$ between sump areas (Table 5). This difference was primarily attributed to significantly higher total crab densities in Area $1(95 \%$ confidence interval [CI]: 536 to $1001 \mathrm{crab} / \mathrm{ha}$ ) as compared with Area 2 (95\% CI: 268 to $642 \mathrm{crab} / \mathrm{ha})$ based on Tukey's pairwise comparison test $(p=0.032)$.

\subsubsection{Post-Hoc Power Analysis}

Post-hoc power analysis showed there was a good likelihood of detecting significant differences between sump areas in the density of total crab and total female crab ( $86 \%$ and $96 \%$, respectively), given sample sizes of 37 (min reps / area) at $\alpha=0.05$ (Table 6). However, the power for total males was very low $(57 \%)$ at the same levels, indicating there was a $43 \%$ chance of committing Type II error (i.e., not detecting a significant difference). At 80\% power, the minimum detectable difference was $189 \mathrm{crab}$.

\subsubsection{Crab Depth Distribution Analysis}

Chi square analysis did not refute the null hypothesis that crab were distributed proportionally by area with regard to age and sex $(p=0.106)$. In other words, crab of various age classes and sex categories were proportionally distributed among the three sump areas.

Regression analyses showed no significant relationships between densities of total (both sex), total male, and total female crab by trawl depth. Therefore, trawl depth was not a good predictor of total crab density, although it should be noted that the range of depths observed was fairly narrow ( $26 \mathrm{ft}$ to $36 \mathrm{ft}$ ).

\subsection{Other Species}

Fishes dominated catches numerically, although Crangon shrimp, mysids, razor clams (Siliqua patula), and cnidarians (jellyfish) were also observed in trawl catches. Presence and absence of mysids and cnidarians was noted in samples, whereas Crangon shrimp and razor clams were quantified. A total of 8,817 Crangon and 3 razor clams were collected from all trawls over the course of the sampling effort. 


\subsubsection{Fish Community Composition and Density}

Over 11,500 individual fishes, representing at least 26 major taxa, were collected from all sump areas over the course of the sampling period (Table 7). No ESA-listed species (e.g., salmon or sturgeon) were collected in any trawl. Pacific tomcod (Microgadus proximus) dominated catches numerically, followed by whitebait smelt (Allosmerus elongatus), Northern anchovy (Engraulis mordax), staghorn sculpin (Leptocottus armatus), and English sole (Pleuronectes vetulus). Densities of these five species exceeded 100 individuals per hectare. Table 7 provides a summary of the total number of individuals collected, mean density, and mean and range of sizes in total length (TL) for each taxonomic grouping. Lengthfrequency distribution graphs of the most abundant fish species are provided in the Appendix.

Species diversity was highest in Area 1 (Table 8), by virtue of several rare species (e.g., cabezon, pile surfperch, redtail surfperch) not collected in other areas. Total fish density was highest in Area 2, specifically due to high densities ( $>500 /$ ha) of Pacific tomcod and whitebait smelt (Table 9). With few exceptions, species composition and relative abundance was fairly similar between areas.

There were some temporal trends in fish densities. Over time, total fish densities ranged between 3500 and 500 individuals/ha, with numerically dominant species such as Pacific tomcod and Whitebait smelt driving much of the overall trends (Figure 12). A steep decline in Pacific tomcod and smelt abundance was observed after mid-September.

\subsection{Physical Properties: Depth, Water Temperature, and Salinity}

\subsubsection{Trawl Depth Data}

As mentioned in Section 3.1, bottom depths measured during trawling efforts were significantly different in each of the sump areas (ANOVA, $p<0.001$ ). Area 1 was the shallowest at $30.5 \mathrm{ft}$, followed by Area 3 $(33.4 \mathrm{ft})$, and Area $2(38.4 \mathrm{ft})$ (Table 3; Figure 2).

\subsubsection{Water Properties}

Surface and bottom water salinity and temperature measured during trawling generally were indistinguishable between each of the sump areas (Figure 13 and 14). Waters were well stratified, with significantly higher salinities and lower temperatures near the bottom. However, some temporal trends are worth noting. From late July (Trip 2) through early September (Trip 5), bottom temperature generally remained near $8^{\circ} \mathrm{C}$. In late September (Trip 6), bottom temperatures increased to $12^{\circ} \mathrm{C}$ and remained elevated throughout the remaining sampling effort. Surface temperatures likewise declined. Although water temperatures indicated a reduction in water column stratification during later sampling efforts, salinities did not exhibit the same trend.

\subsection{Summary of Results}

- Nine sampling trips, involving a total of 113 trawls covering over 7.4 ha, were conducted between July 8, 2003, and November 1, 2003.

- Dungeness crab were present in each of the alternative sump areas throughout the duration of the sampling effort. The mean density of all crab (all sexes and age classes combined) in the three areas over the entire study period was $613 \mathrm{crab} / \mathrm{ha}$.

- Soft-shell crabs were not abundant in any area, and comprised $0.33 \%$ of the total crab catch. 
- Significantly higher total crab densities were detected in Area 1 (769 crab/ha ) as compared with Area 2 (455 crab/ha). Statistical power was generally high, indicating a good likelihood of detecting significant differences with the given sampling effort.

- Over time, total crab densities generally increased, with a sharp jump in crab numbers in midSeptember associated with an influx of Age 1+ crab. In general, Age 2+ crab predominated through early September, before relative abundance shifted to Age 1+ crab. YOY and Age 3+ crab composed a fairly small proportion of the overall catch.

- Age 1+ sex ratios were skewed to males during late September and early October, before shifting toward females in late October and early November.

- With few exceptions, fish species composition and relative abundance was fairly similar between each of the alternative sump areas. No ESA-listed species were collected in any trawl.

- Area 1 was significantly shallower than either Area 2 or Area 3.

- Surface and bottom temperature and salinity generally were indistinguishable between each of the study areas. Bottom temperatures increased an average of $4^{\circ} \mathrm{C}$ in late September. 


\subsection{Discussion}

\subsection{Comparison of Crab Densities}

Crab densities observed in the sump areas over the course of this study appear to be within the range of densities reported elsewhere, especially for Age 1+ crabs in what has been described as "lower main channel" habitat by Rooper et al. (2002). Total crab densities measured in the sump areas over the course of this study averaged $613 \mathrm{crab} / \mathrm{ha}$, with catches composed primarily of Age $1+(421 \mathrm{crab} / \mathrm{ha})$ and Age $2+$ (122 crab/ha) crab. Mean Age 1+ crab densities for each sump area in the MCR ranged from 301 (Area 2) to $541 \mathrm{crab} / \mathrm{ha}$ (Area 1) from July to November 2003. Rooper et al. (2002) surveyed crab densities in four West Coast estuaries using a 3-m plum-staff beam trawl of the same design used here, and found that Dungeness crab showed consistent use of some estuarine habitats. Despite considerable year-to-year variability, mean annual densities of Age 1+ crab in the "lower main channel habitats" examined by Rooper et al. (2002) in June and August ranged from approximately 200 to $600 \mathrm{crab} / \mathrm{ha}$ in Yaquina Bay and Coos Bay, 200 to $1600 \mathrm{crab} / \mathrm{ha}$ in Grays Harbor, and 200 to $1200 \mathrm{crab} / \mathrm{ha}$ in Willapa Bay.

Rooper also found that "lower side channel" habitats near the mouth of all four estuaries had the highest densities of Age 1+ crab (usually over $1000 \mathrm{crab} / \mathrm{ha}$ ), whereas "lower estuarine main channel" and "upper estuary" habitats had significantly lower densities of Age 1+ crab (usually below $500 \mathrm{crab} / \mathrm{ha}$ ) (Table 10). The habitat characteristics of these lower side channel subregions include a high percentage of broad intertidal flats, local refuge in the form of shell hash and macroalgae, shallow depths, high food abundance, temperatures less than $18^{\circ} \mathrm{C}$, and relatively high salinities (above 25\%o). Lower side channel habitats in the MCR would likely include areas such as Baker Bay.

The age composition and density of crab from this study generally differ from previous investigations conducted in the Columbia River Estuary, which may be attributed to differences in sampling gear, interannual variability in crab populations or movement, and the spatial distribution of sampling stations. Previous studies of crab distribution within the Columbia River estuary include those of Emmett and Durkin (1985), McCabe et al. (1986), McCabe and McConnell (1989), and Larson (1993). All of these studies were based on monthly sampling with an 8-m shrimp trawl of stations broadly distributed within the Columbia River Estuary. McCabe et al. (1986) noted that crab populations associated with the Columbia River Bar were predominantly composed of YOY crab entering the estuary from the ocean, which increased in density during the spring and summer of both years. Interannual abundance varied substantially, with the highest YOY crab densities observed in 1985 (>600 crab/ha) and less than 50 crab/ha observed in 1986 to 1988 (Larson 1993). Of the six subtidal stations that made up the Columbia River Bar "region" in McCabe et al. (1986), Station 26 (also referred to as Station "F" in Larson 1993) was the northernmost station and the only sampling location in close proximity to the sump areas. Averaged over all years and months, crab abundance was considerably higher at Station 26 than all other stations in the Bar region, with mean YOY crab densities of $>600 \mathrm{crab} / \mathrm{ha}$ and older $\mathrm{crab}$ (Age $1+$ and greater) densities of 40 to $60 \mathrm{crab} / \mathrm{ha}$ (Larson 1993).

It should be noted that gear efficiency was not accounted for in any of the crab density calculations in this study or those cited above. All sampling methods have some associated inefficiencies that vary with species, individual size or mobility, and bottom type. Stevens and Armstrong (1984) have suggested that the 3-m beam trawl samples newly settled YOY crab with an efficiency factor of 0.03, larger YOY crab at an efficiency of 0.25 , and larger crab age groups at an efficiency factor of 0.5 . Gear efficiency should therefore be considered in any future population estimates. 


\subsection{Differences in Crab Densities among Sump Areas}

The sump areas differed significantly with regard to crab density, with Area 1 having significantly higher densities (769 crab/ha) than Area 2 (455 crab/ha). Area 1 was the shallowest and easternmost sump area, and also consistently had the highest number of crab pots observed during the sampling, suggesting that crab fishermen are keying in to aspects of local crab distribution and abundance.

Soft-shell crabs occurred in all three sump areas and were in low abundance $(0.33 \%$ of total crab catch) throughout the study. Previous studies have similarly not indicated that soft-shell crab were a dominant component of the crab population in the study region. One sump area could not be distinguished from another in terms of soft-shell abundance.

\subsection{Differences in Crab Densities with Season}

Crab density varied by season, with an abrupt and substantial increase in Age 1+ Dungeness crab densities in late September 2003 that extended through the end of sampling in November 2003. Crab densities averaged less than $500 \mathrm{crab} / \mathrm{ha}$ in the summer (July through early September) to over 500 $\mathrm{crab} / \mathrm{ha}$ in the fall (late September through November). These observations coincide with some of the findings of Armstrong et al. (1987), who provided evidence of movements of Age 1+ and older crab to and from estuarine and nearshore areas of Grays Harbor and Willapa Bay. To summarize, Armstrong and colleagues observed recurring size anomalies during the mid- to late-summer, when Age 1+ crab smaller than expected occurred in the estuary and Age 1+ crab larger than expected appeared in nearshore samples (see Figure 2.17 in Armstrong et al., 1987). They attribute these size anomalies to mixing of two crab subpopulations: the slower growing subpopulation of nearshore origin and the faster growing subpopulation of estuarine origin. Under this scenario, a portion of the nearshore Age 1+ crab subpopulation (i.e., those crabs that settled as megalopae into coastal habitats) immigrate into the estuary to join the resident Age 1+ population (Figure 15). Estuarine growth is enhanced relative to colder nearshore areas, and as Age 1+ crabs reach sizes near or greater than $100-\mathrm{mm} \mathrm{CW}$, they emigrate from the estuary during late summer or fall. Female crabs do not return again in appreciable numbers, although males larger than 110- to $120-\mathrm{mm} \mathrm{CW}$ may mix somewhat across the estuarine mouth.

Armstrong et al.'s (1987) synopsis of crab movement timing and residency between and within-estuary and nearshore habitats (Figure 15) may be applicable to the Columbia River Estuary. Under this conceptual framework, the pulse of Age 1+ crab observed in the sump alternative areas beginning in late September represents the mixing of nearshore and estuarine subpopulations, especially nearshore Age $1+$ crab of a smaller size (50-70 mm CW) moving into the MCR (Figure 16). Water temperature may play a role in initiating seasonal movement into the estuary, as indicated by the rise of bottom temperatures that coincided with the pulse of Age 1+ crab in the study area. Larger Age 1+ crab $(80-100 \mathrm{~mm} \mathrm{CW})$ that were also periodically abundant in the sump alternative areas during the early August and early October sampling efforts, and may represent outmigrating crab from estuarine subpopulations. However, without concurrent sampling in nearshore and upper estuary habitats (e.g., Baker Bay), we can only speculate about whether these subpopulations actually exist in the MCR and whether they are the source of Age 1+ crab found in the alternative sump areas. With the current information, it is still unclear whether the aggregation of Age 1+ crab found in the sump areas during the fall represents temporary movement through a migratory corridor or seasonal use of an over-wintering area. Questions still remain about the relative value of these sump areas to crab population dynamics in the MCR, and the environmental cues eliciting seasonal movement and other behavior. 


\subsection{Implications}

Overall, average crab densities were significantly higher in Area 1 than in Area 2, and higher in the fall than summer. To understand the potential risk of impacts to Dungeness crab associated with entrainment using a pipeline dredge, we recommend running a modification of a Dredge Impact Model (DIM) first developed by Armstrong and his colleagues (Armstrong et al., 1987; Wainwright et al., 1992). Pearson et al. $(2002,2003)$ adapted this DIM to successfully accept direct measurements of entrainment rates and then to estimate adult equivalent loss (AEL) of Dungeness crab from dredging in the MCR and Lower Columbia River. With some assumptions, the current study may similarly provide sufficient information (crab densities by age class, sex, and season) to model potential dredging impact risks to crab populations at each of the proposed sump areas.

\subsection{Conclusions and Recommendations}

- To understand the relative risk of losses to crab populations associated with dredging impacts at the sump alternative areas, it is recommended that a modified DIM be developed using the data collected in this study. This model should estimate crab AEL and associated error rates to gain a population-level perspective on the potential entrainment impacts at each of the three alternative sump areas.

- Age 1+ crab appear to be aggregating in the sump alternative areas during the fall. Episodic pulses of Age 1+ crab in the MCR may represent mixing of two subpopulations, as reported in other Pacific Northwest coastal estuaries by the existing literature. However, it is currently unclear what the relative value of the sump areas are as possible migratory corridors or overwintering grounds for segments of the MCR crab population. A comprehensive and sustained (multi-year) survey of Dungeness crab distribution and movement in Columbia River nearshore and estuarine habitats would enable better decision making about management practices for a variety of issues associated with dredged material handling and disposal.

- The MCR is a dynamic environment, not only from a physical standpoint, but also with regard to biological complexity and human-use interactions. Such dynamics led to a number of project challenges, at both the design and implementation levels, that were met by the informed use of statistics, biology, and physical oceanography. As well, outreach efforts to the local fishing community helped avoid a number of operational conflicts in the study area, and should be continued with any future work in the region. 


\subsection{References}

Antrim, L.D., and B.D. Gruendell. 1998. Effects of Sand Accumulation on Juvenile Flatfish and Softshelled Dungeness Crab. PNNL-12062. Prepared for the U.S. Army Corps of Engineers, Portland District, by Pacific Northwest National Laboratory, Richland, Washington; Battelle Marine Sciences Laboratory, Sequim, Washington.

Armstrong, D. A., T. C. Wainwright, J. Orensanz, P. A. Dinnel, and B. R. Dumbauld. 1987. Model of Dredging Impact on Dungeness Crab in Grays Harbor, Washington. FRI-UW-8702. Fisheries Research Institute, University of Washington, School of Fisheries; Seattle, Washington.

Emmett, R. L., and J. T. Durkin. 1985. "The Columbia River Estuary: An Important Nursery for Dungeness Crabs." Marine Fisheries Review 47:21-25.

Gunderson, D. R., and I.E. Ellis. 1986. "Development of a plumb staff beam trawl for sampling demersal fauna." Fisheries Research 4:35-41.

Gunderson, D. R., D. A. Armstrong, Y. Shi, and R. A. McConnaughey. 1990. "Patterns of estuarine use by juvenile English sole (Parophrys vetulus) and Dungeness crab (Cancer magister)." Estuaries 12: 5971.

Larson, K. W. 1993. Entrainment of Dungeness Crabs by Hopper Dredge at the Mouth of the Columbia River, OR and WA. U.S. Army Corps of Engineers, Portland District; Portland, Oregon.

McCabe, G. T. Jr., R. L. Emmett, T. C. Coley, and R. J. McConnell. 1986. Distribution, abundance, and size-class structure of Dungeness crab in the Columbia River Estuary. Contract DACW57-84-F-0178. National Marine Fisheries Service, Seattle, Washington. Final Report to Portland District, U.S. Army Corps of Engineers, Portland, Oregon. 57 pp.

McCabe, G. T. Jr., and R. J. McConnell. 1989. Abundance and size-class structure of Dungeness crab in or near frequently dredged areas in the Columbia River estuary. National Marine Fisheries Service, Seattle, Washington. Report to Portland District, U.S. Army Corps of Engineers, Portland, Oregon. 22 pp.

Miller, B., D. Gunderson, P. Dinnel, R. Donnelly, D. Armstrong, and S. Brown. 1990. Recommended guidelines for sampling soft-bottom demersal fishes by beach seine and trawl in Puget Sound. Prepared by PTI Environmental Services for U.S. Environmental Protection Agency and Puget Sound Water Quality Authority. 39 pp. + Appendices

Pearson, W.H., G.D. Williams, and J.R. Skalski. 2002. Estimated Entrainment of Dungeness Crab During Dredging for the Columbia River Channel Improvement Project. PNL-14129. Prepared for the U.S. Army Corps of Engineers, Portland District, by Battelle/Marine Sciences Laboratory, Sequim, Washington, Pacific Northwest Laboratory, Richland, Washington.

Pearson, W.H., G.D. Williams, and J.R. Skalski. 2003. Estimated Entrainment of Dungeness Crabs During Maintenance Dredging of the Mouth of the Columbia River, Summer 2002. PNNL-14190. Prepared for the U.S. Army Corps of Engineers, Portland District, by Battelle Marine Sciences Laboratory, Sequim, Washington; Pacific Northwest National Laboratory, Richland, Washington. 
Rooper, C.N, D.A. Armstrong, and D.R. Gunderson. 2002. "Habitat Use by Juvenile Dungeness Crab in Coastal Nursery Estuaries." In Crabs in Cold Water Regions: Biology, Management, and Economics. Alaska Sea Grant College Program, Publication AK-SG-02-01. pp. 609-629.

Simenstad, C.A., C.D. Tanner, R.M. Thom, and L.L. Conquest. 1991. Estuarine Habitat Assessment Protocol. U.S. Environmental Protection Agency, Seattle, Washington.

Stevens, B.G, and D.A. Armstrong. 1984. "Distribution, abundance, and growth of juvenile Dungeness crabs, Cancer magister, in Grays Harbor estuary, Washington." Fishery Bulletin 82:469-483.

Wainwright, T.C., D.A. Armstrong, P.A. Dinnel, J.M. Orensanz, and K.A. McGraw. 1992. "Predicting the effects of dredging on a crab population: An equivalent adult loss approach." Fishery Bulletin 90:171-182. 


\subsection{Figures}

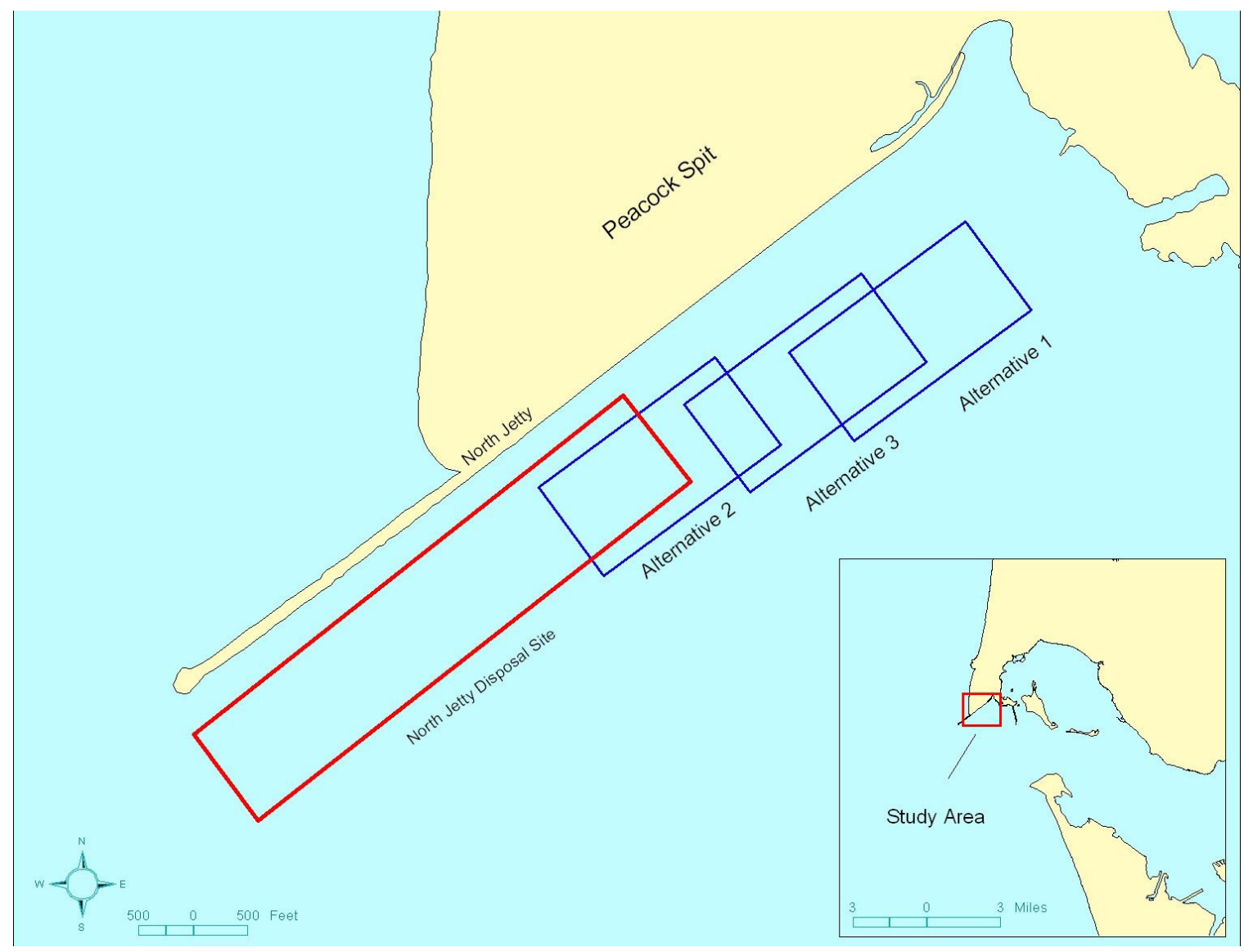

Figure 1. Map of the Study Area, Including the Three Sump Alternative Sites and North Jetty Dredged Material Disposal Site 


\section{Boxplots of Depth by Area}

(means are indicated by solid circles)

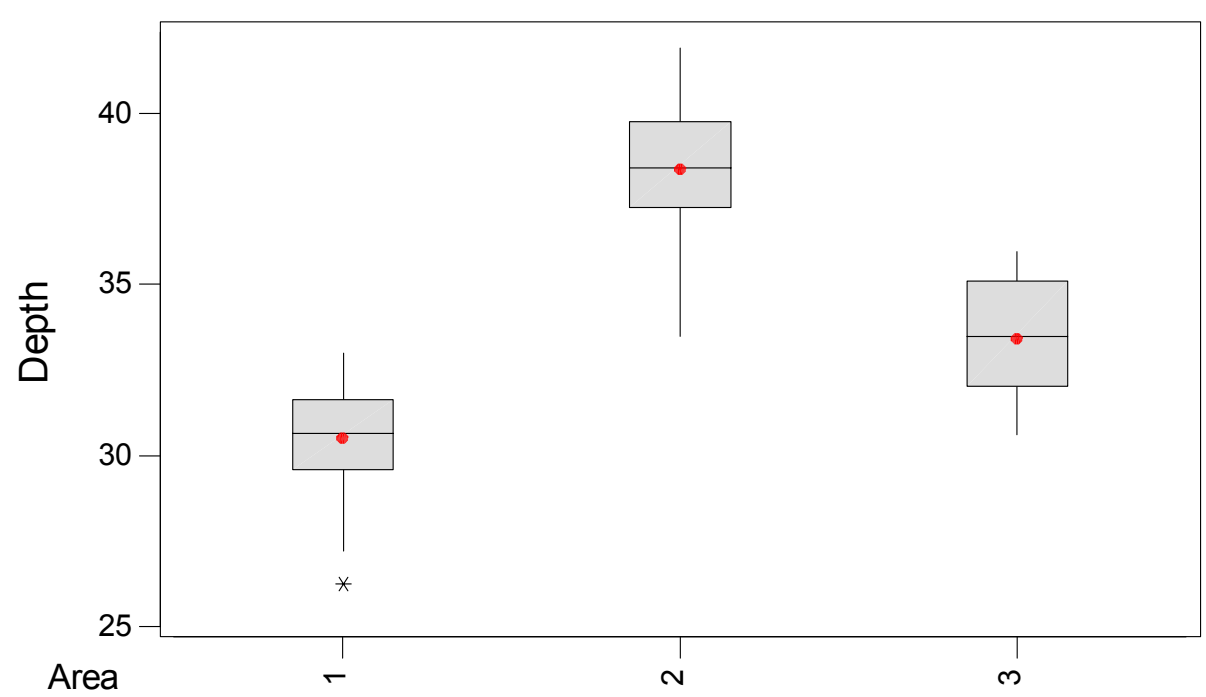

Figure 2. Mean Water Depth (ft) Measured During Trawl Sampling at Each Sump Alternative Area

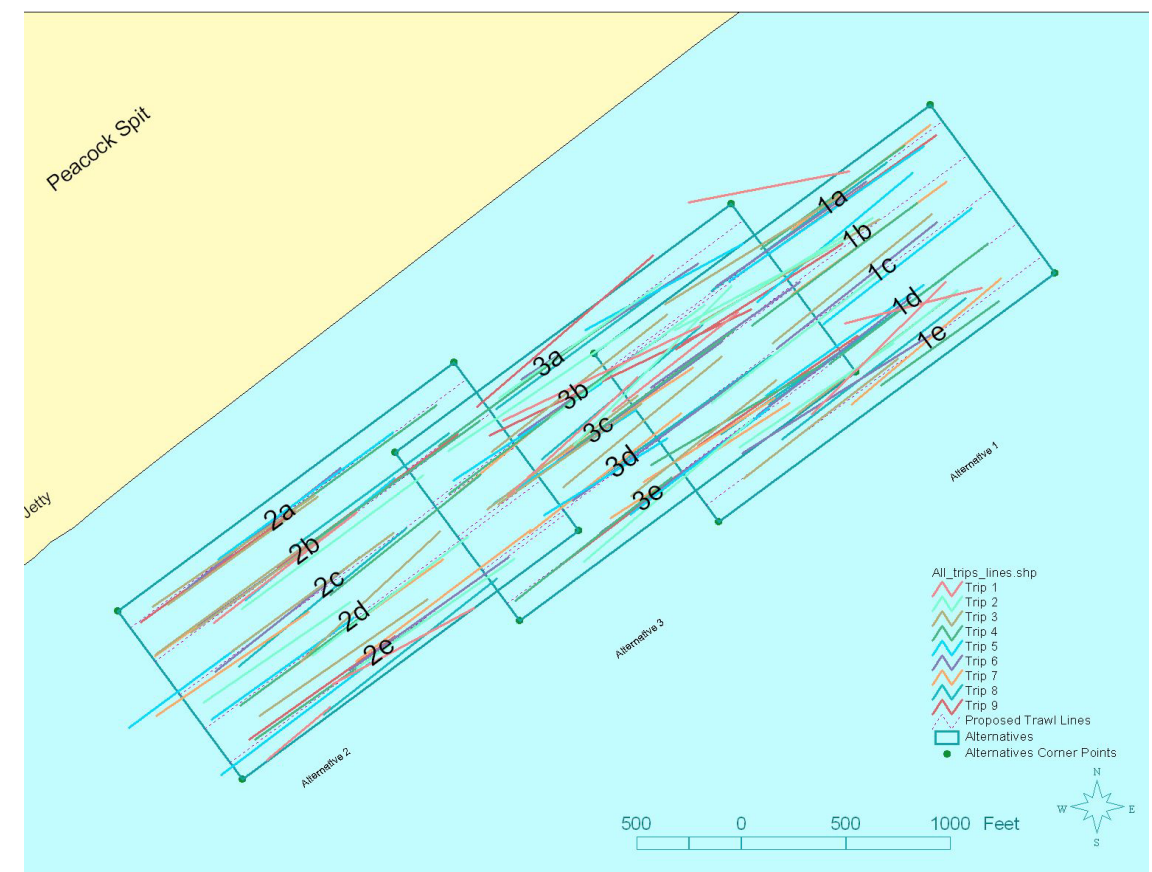

Figure 3. Trawl Sampling Effort, Color Coded by Sampling Date 


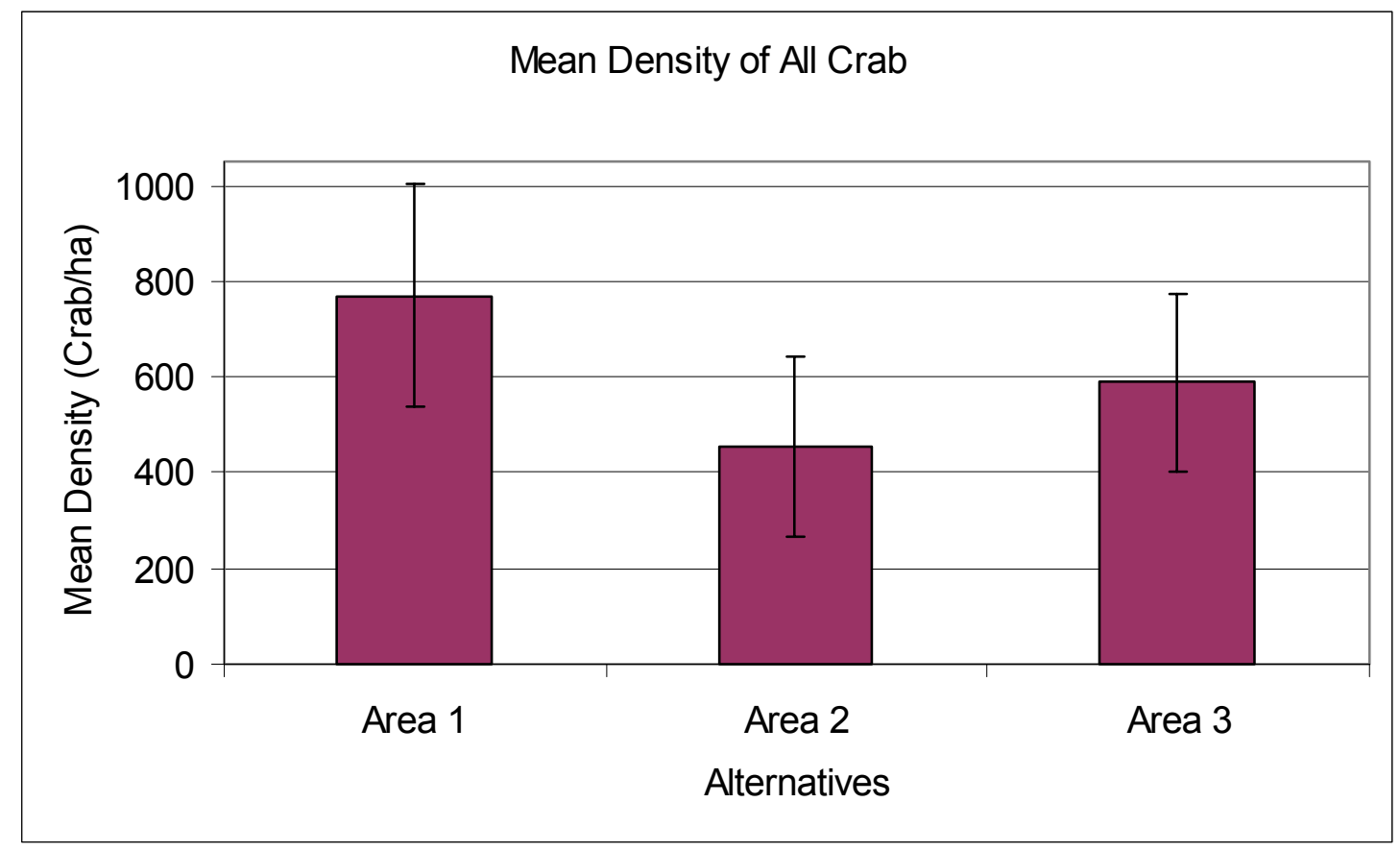

Figure 4. Dungeness Crab Densities Averaged over Entire Sampling Period ( $\pm 95 \%$ Confidence Intervals) by Sump Alternative Area

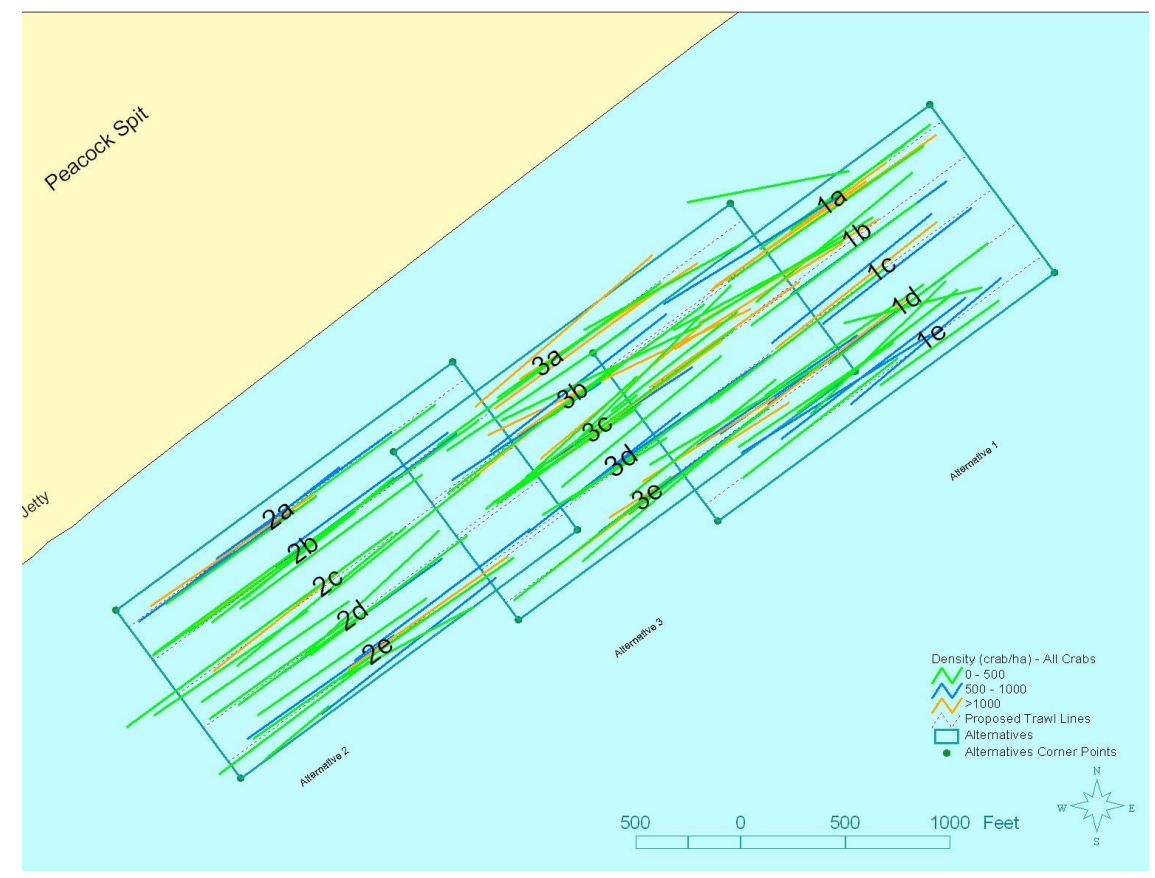

Figure 5. Trawl Sampling Effort, Color Coded by Relative Density of Total Crab in Trawl 

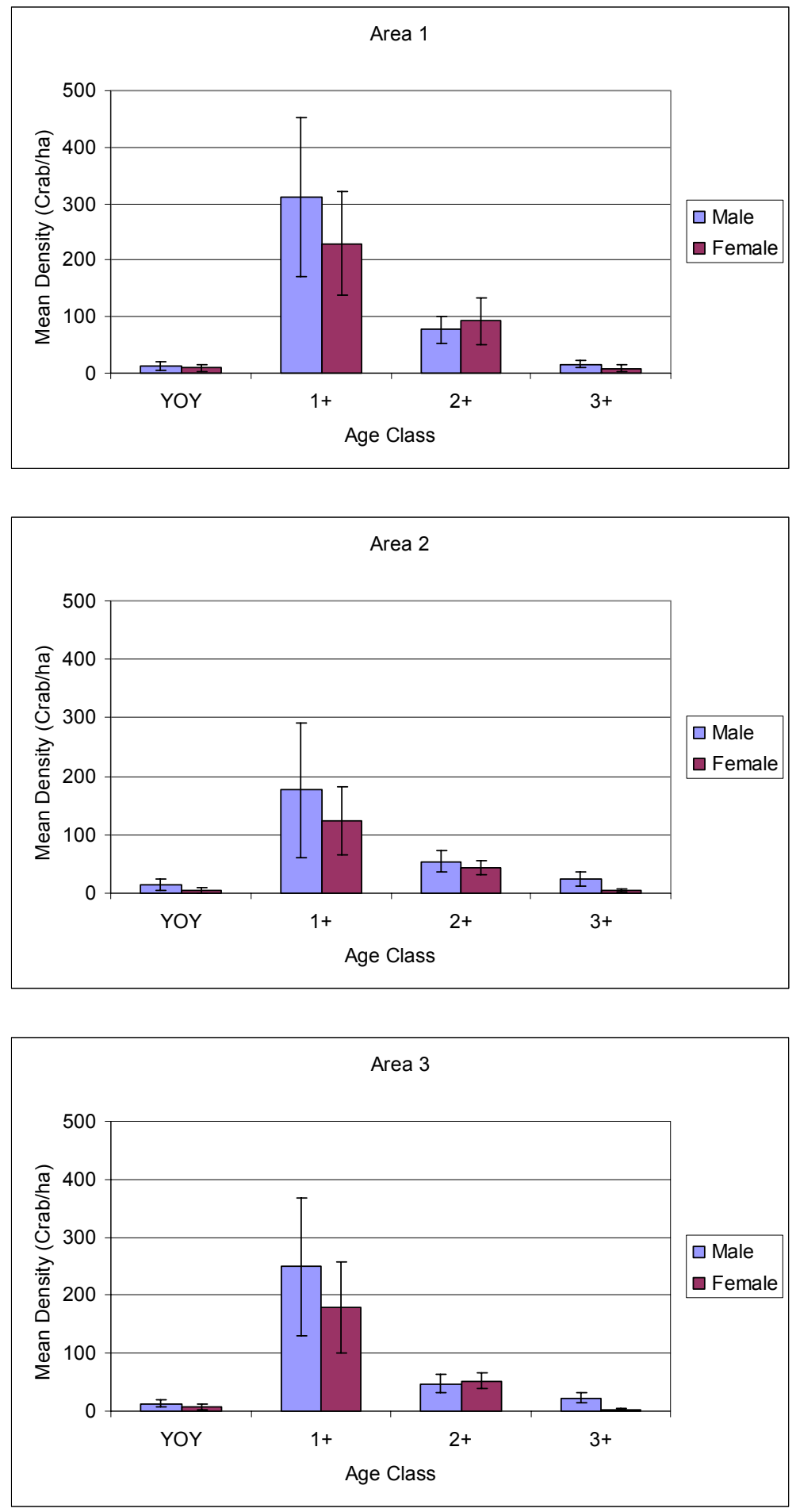

Figure 6. Dungeness Crab Densities (by Sex and Age Class) Averaged Over Entire Sampling Period ( $\pm 95 \%$ Confidence Intervals) by Sump Alternative Area 


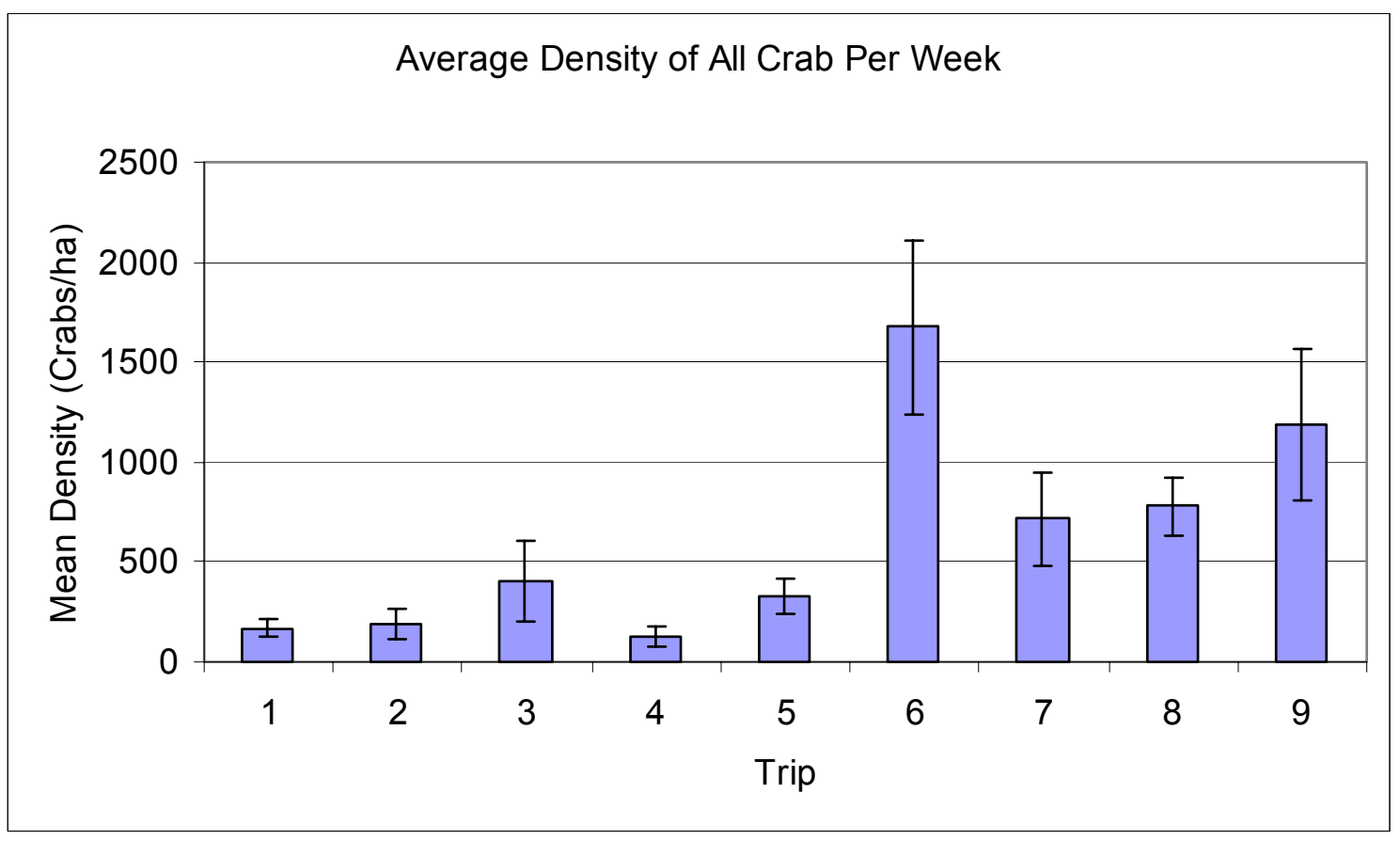

Figure 7. Density of Dungeness Crab Averaged Over All Areas (+/- 95\% Confidence Intervals) by Sampling Trip 

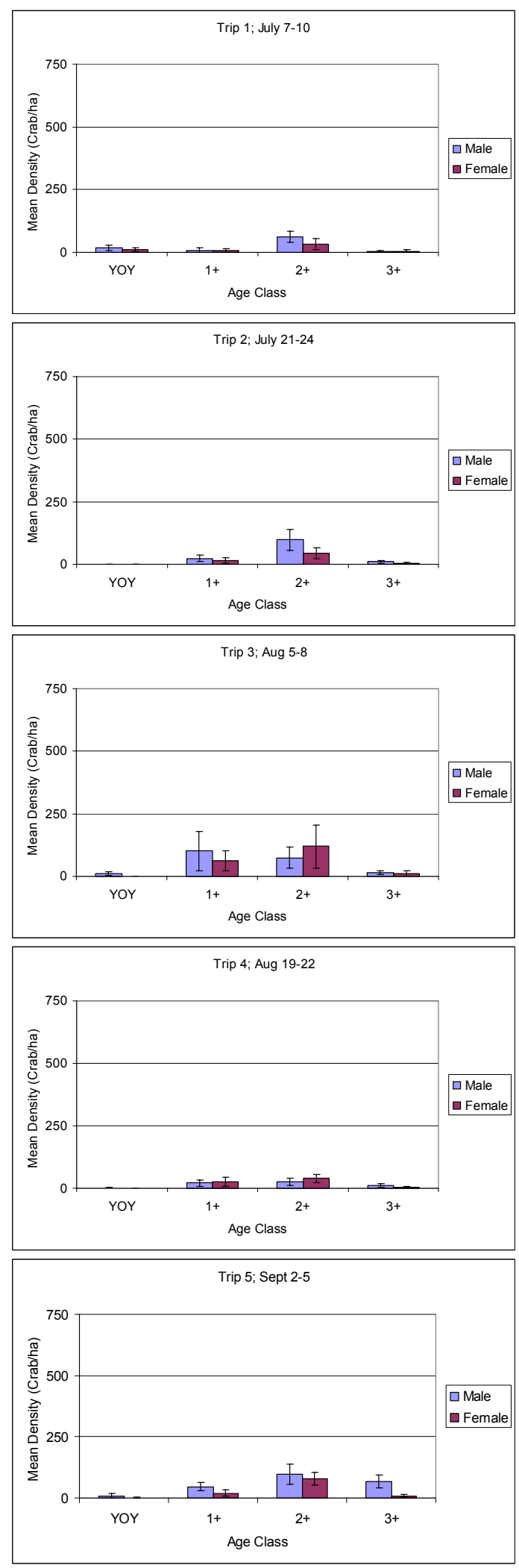

Figure 8. Dungeness Crab Densities (by Sex and Age Class) by Sampling Trip ( $\pm 95 \%$ Confidence Intervals)
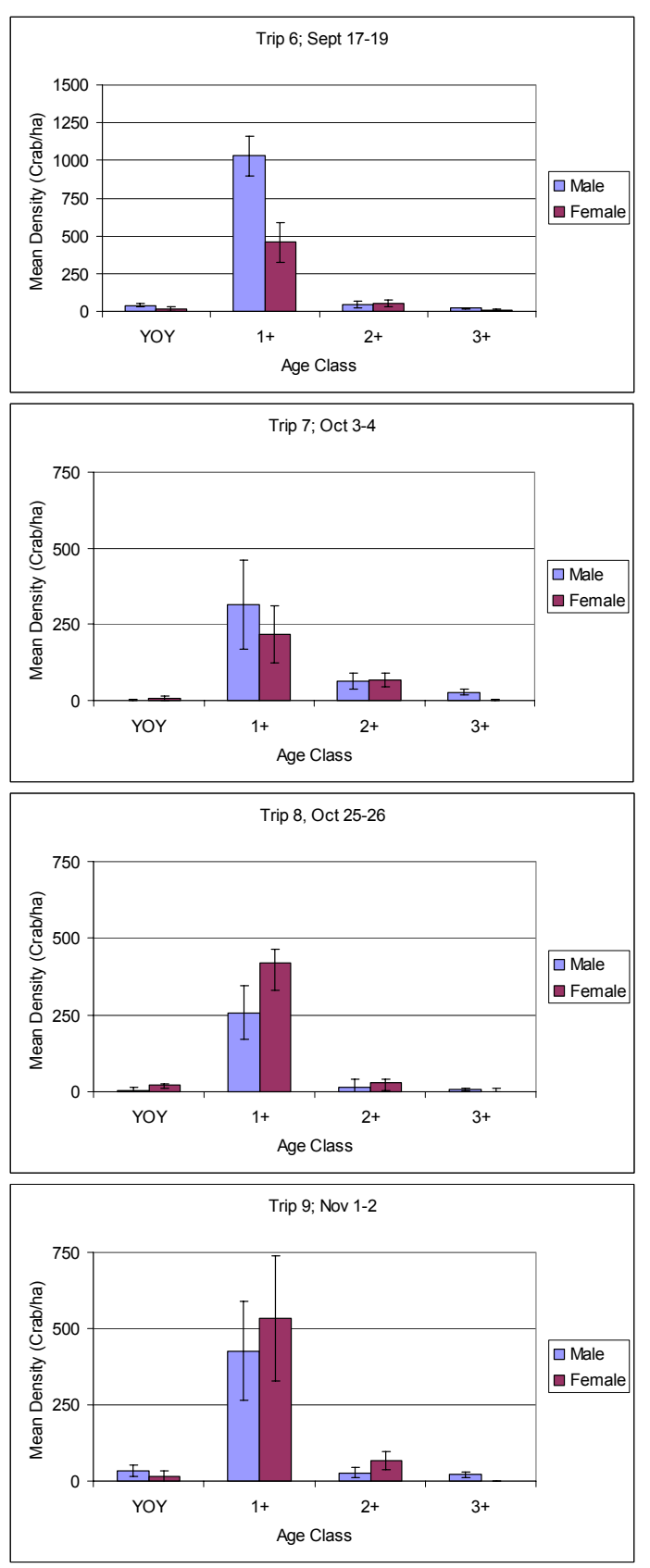
Interaction Plot - LS Means for YOY-US

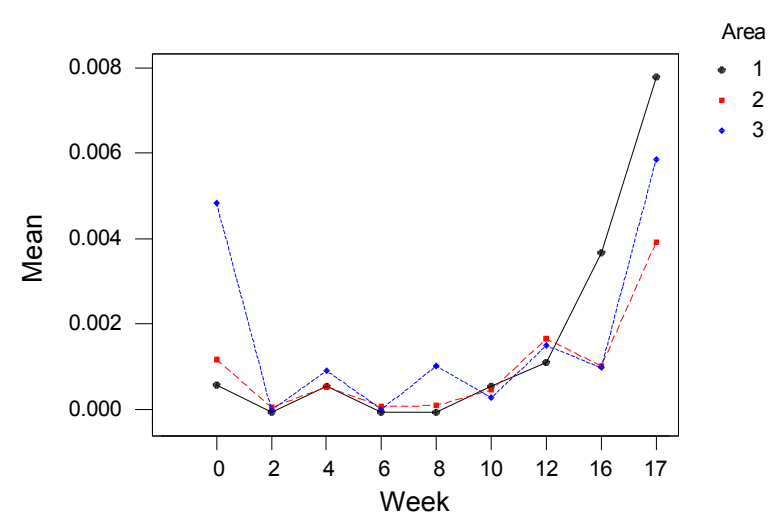

Interaction Plot - LS Means for YOY-M

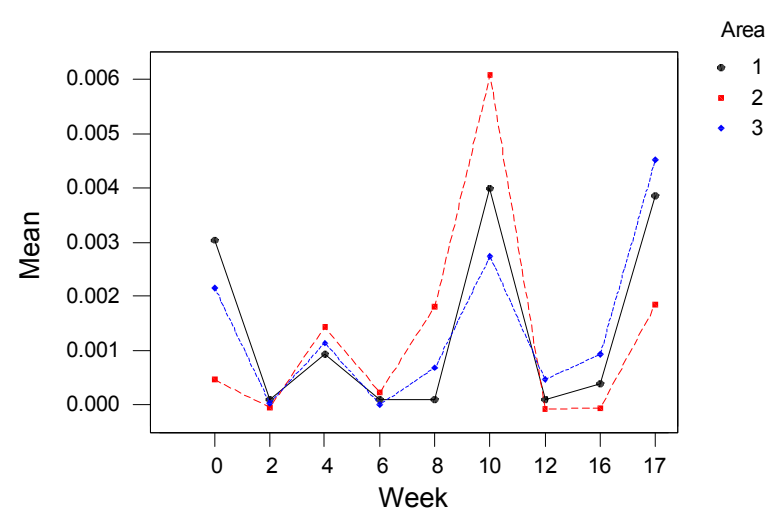

Interaction Plot - LS Means for YOY-F

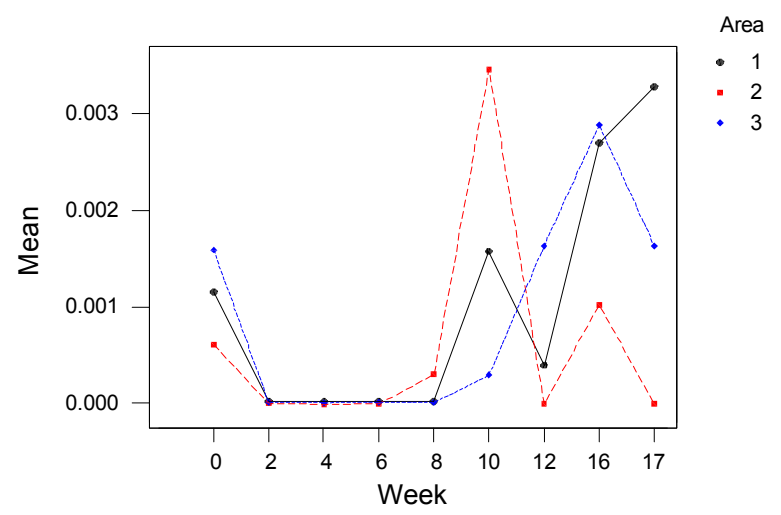

Figure 9. Interaction Plots of Mean Densities of YOY Unsexed (US), Male (M), and Female (F) Dungeness Crab 

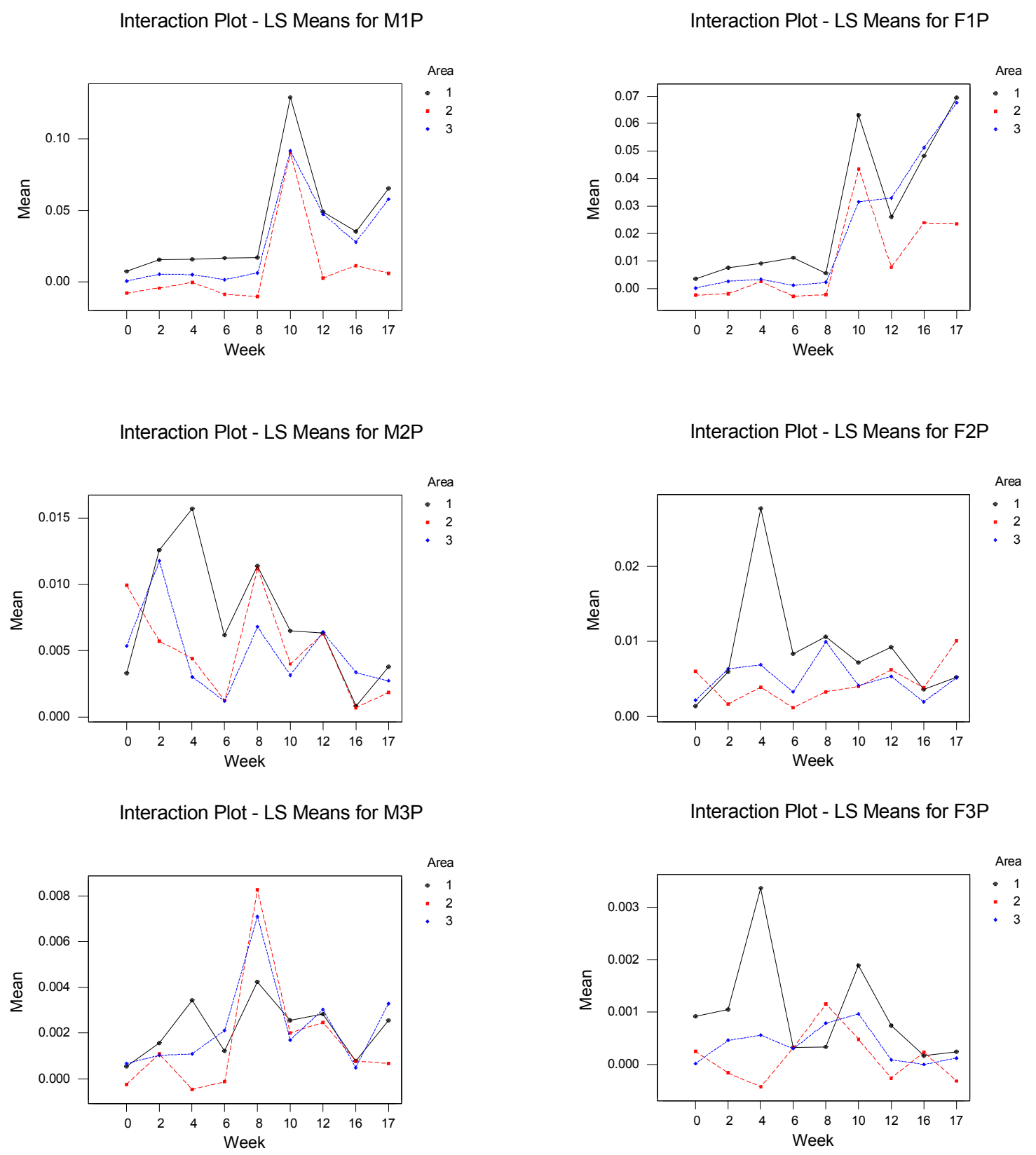

Figure 10. Interaction Plots of Male (M) and Female (F) Age 1+ (1P), 2+ (2P), and 3+ (3P) Dungeness Crab Mean Densities 
Interaction Plot - LS Means for TotM

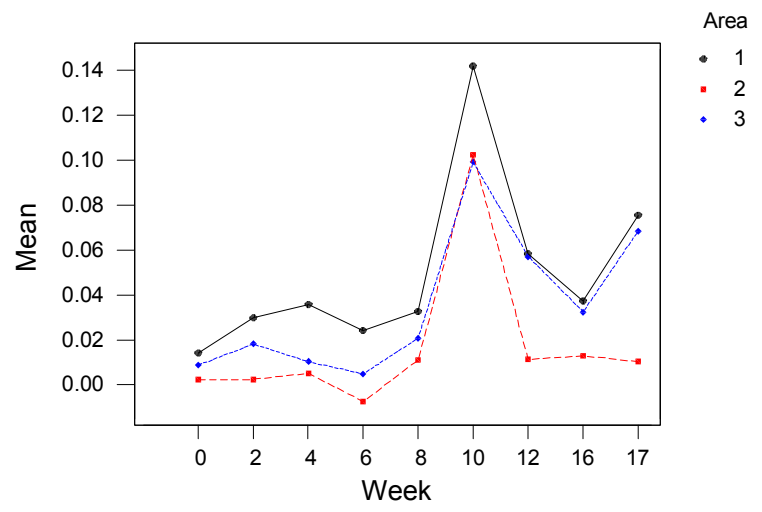

Interaction Plot - LS Means for TotF

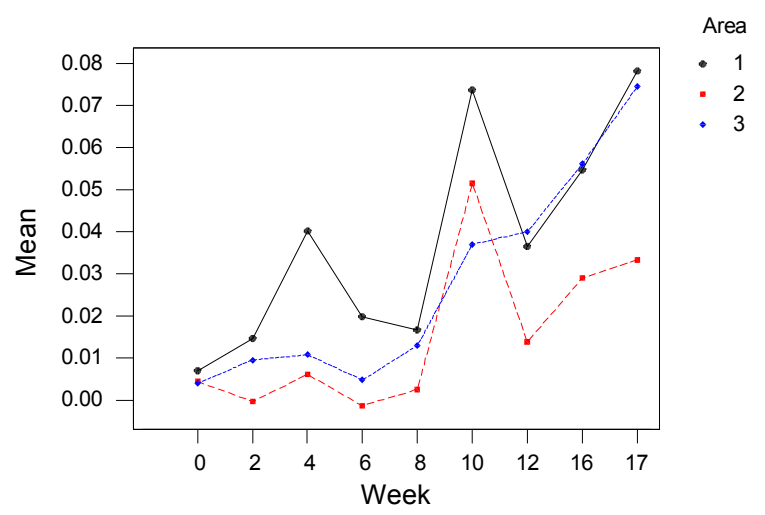

Interaction Plot - LS Means for Total-C

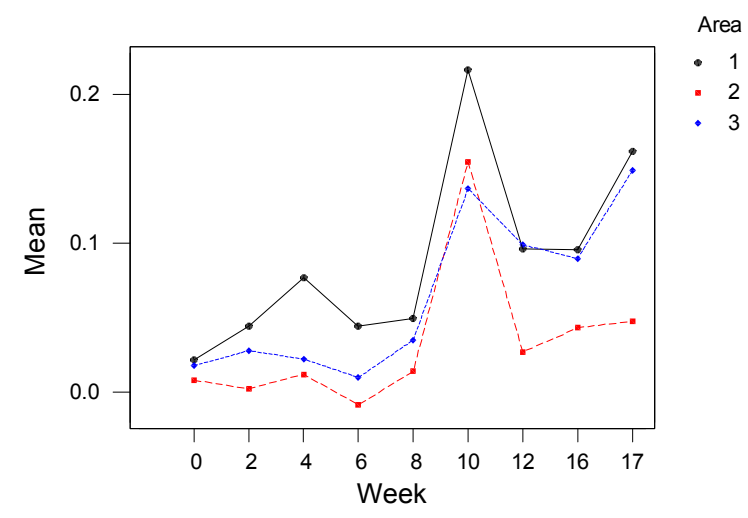

Figure 11. Interaction Plots of Total Male (TotM), Total Female (TotF), and All (Total-C) Dungeness Crab Mean Densities 


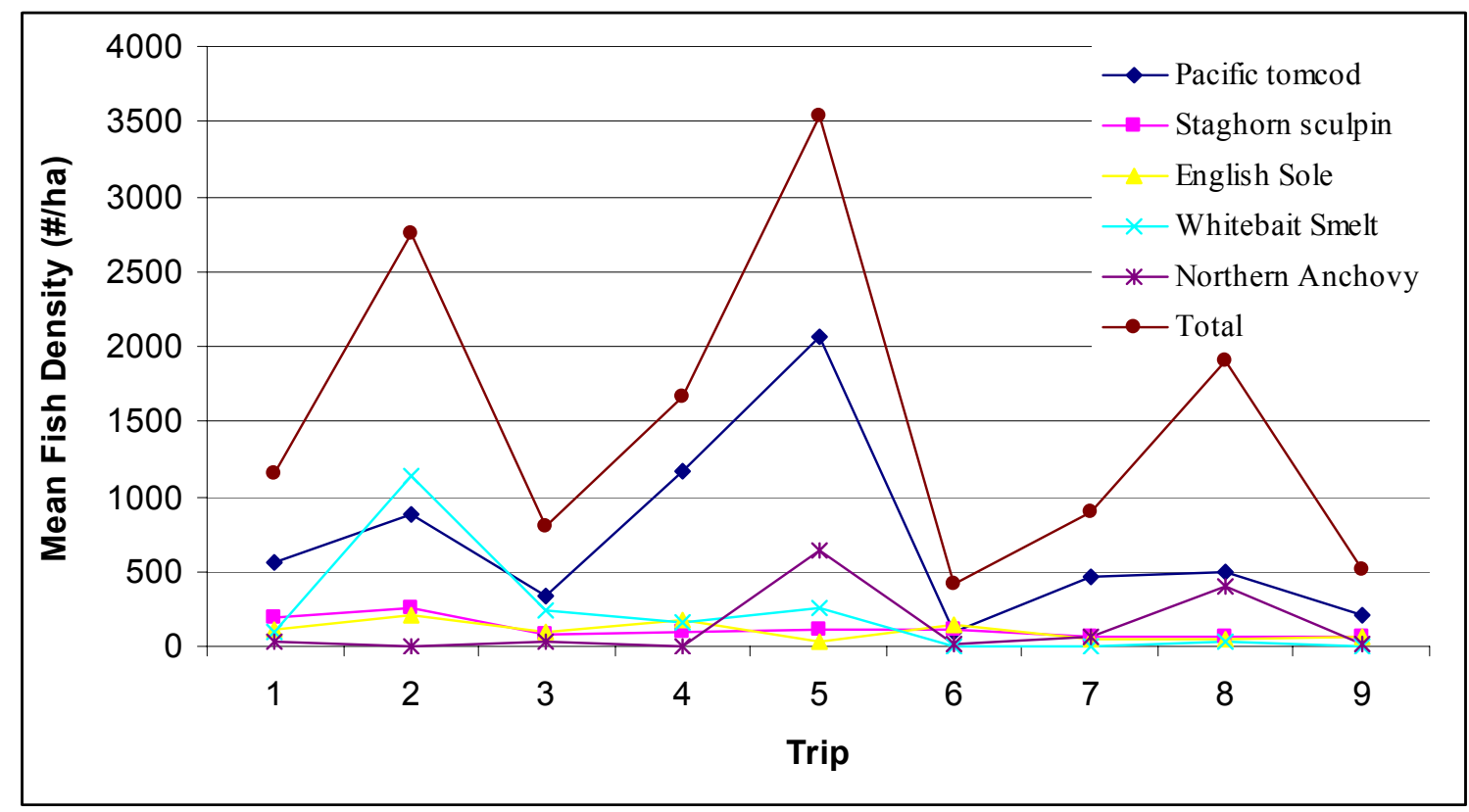

Figure 12. Mean Density of Numerically Dominant Fish Species Over Time

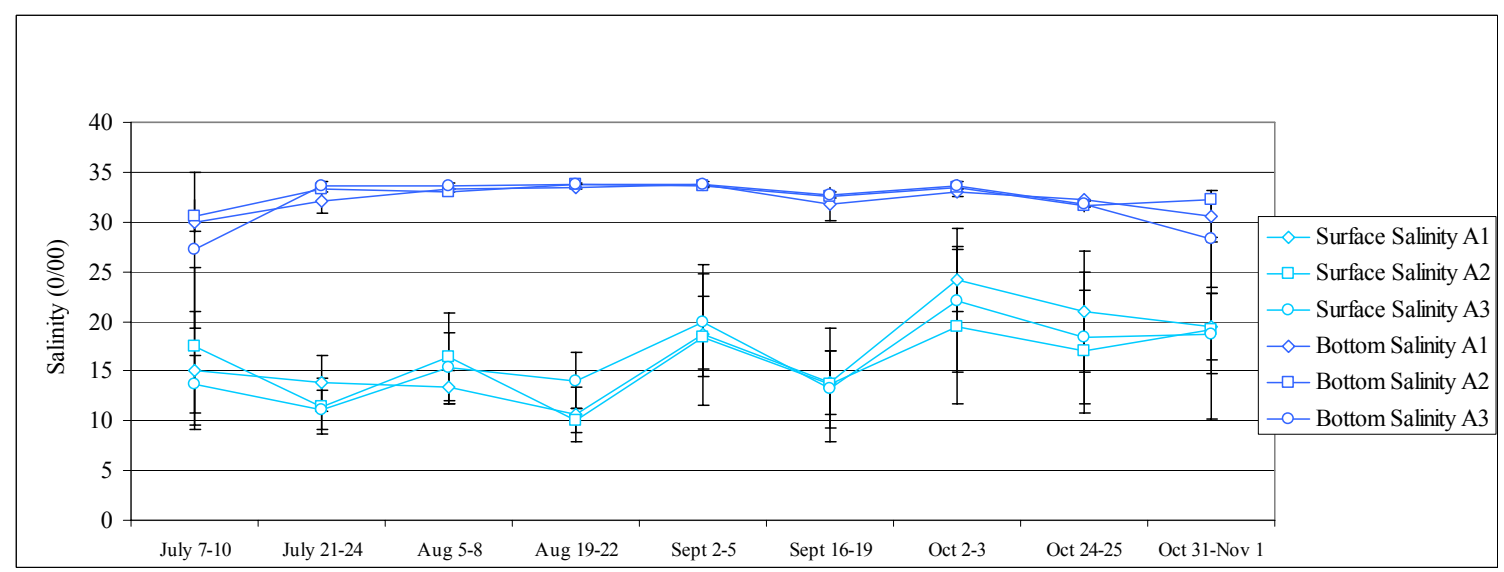

Figure 13. Mean Surface and Bottom Water Salinity ( $\pm 95 \%$ Confidence Intervals) at Each Study Area (A1-A3) 


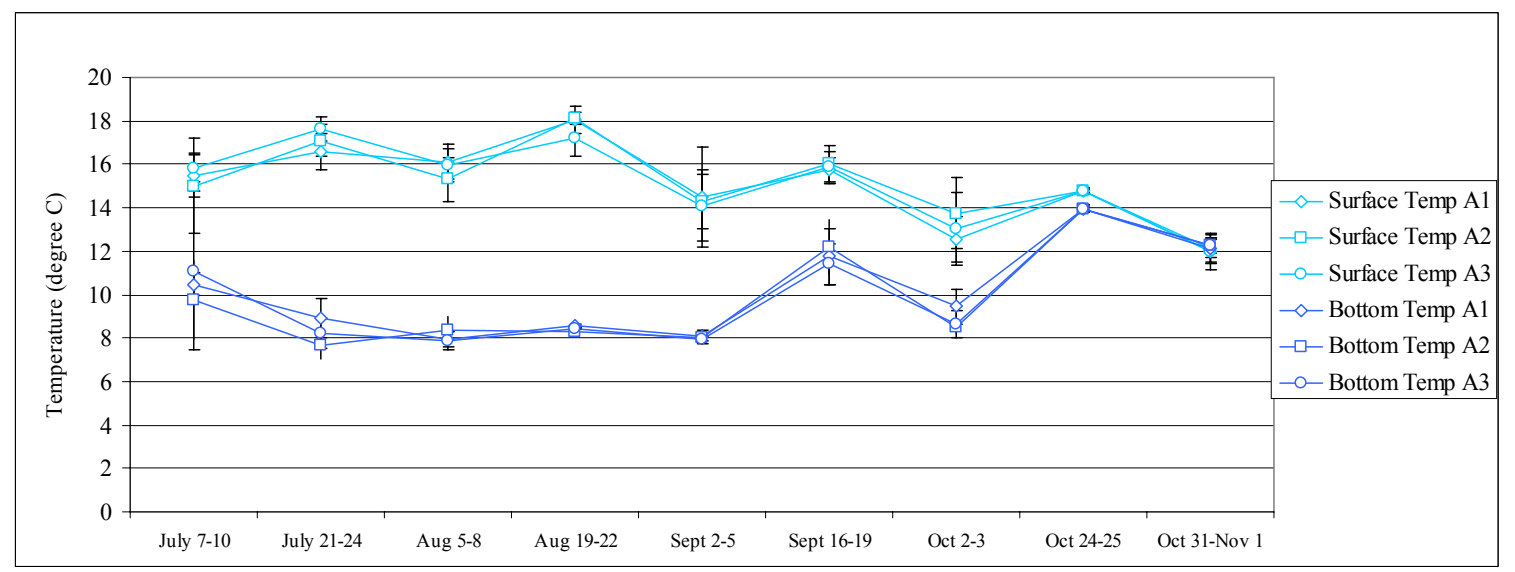

Figure 14. Mean Surface and Bottom Water Temperature ( $\pm 95 \%$ Confidence Intervals) at Each Study Area (A1-A3)

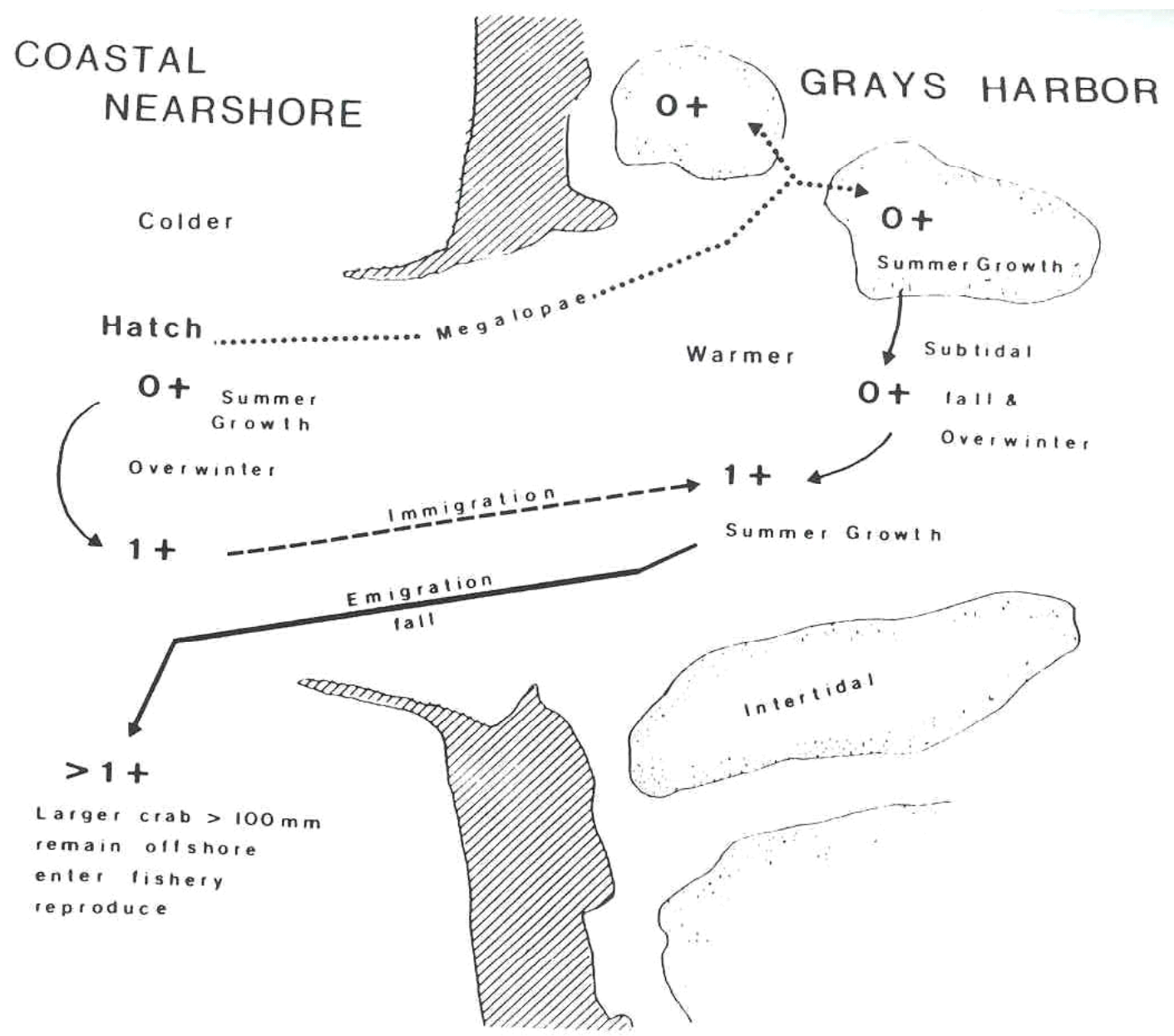

Figure 15. Generalized Movements of Juvenile Dungeness Crab to and from Grays Harbor and the Nearshore Environment (from Armstrong et al. 1987) 

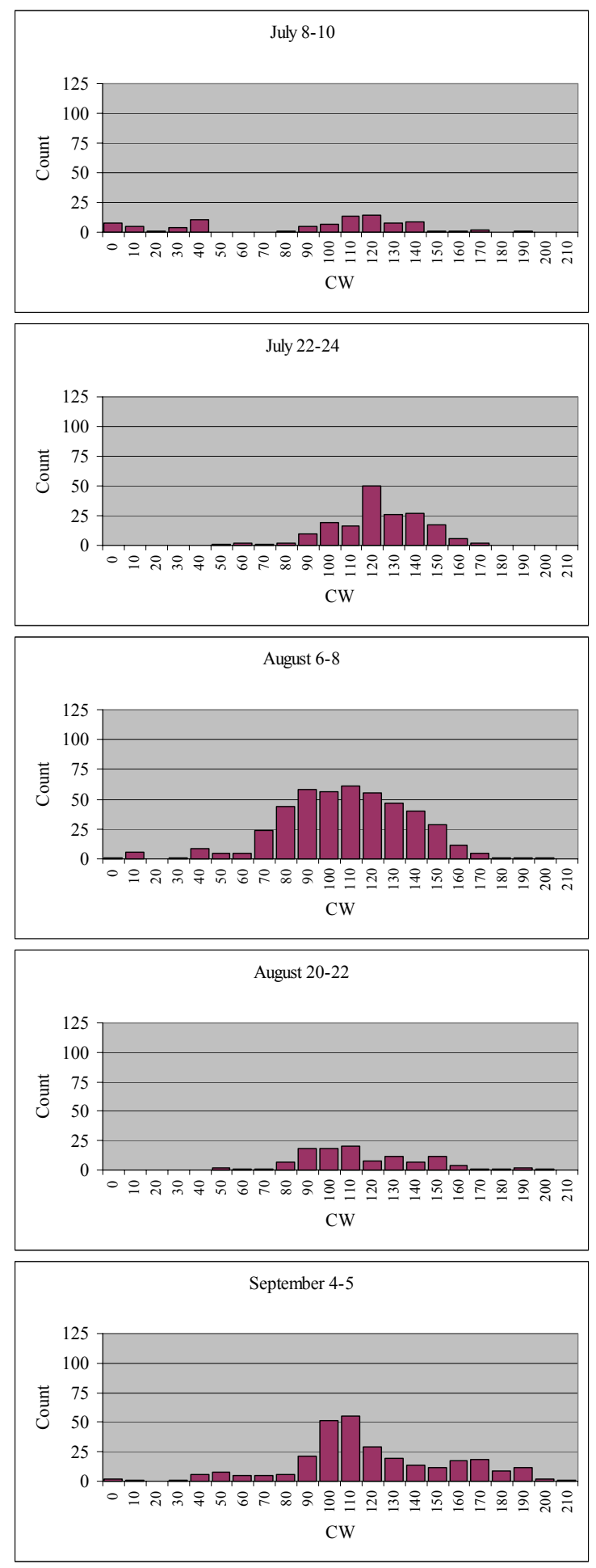
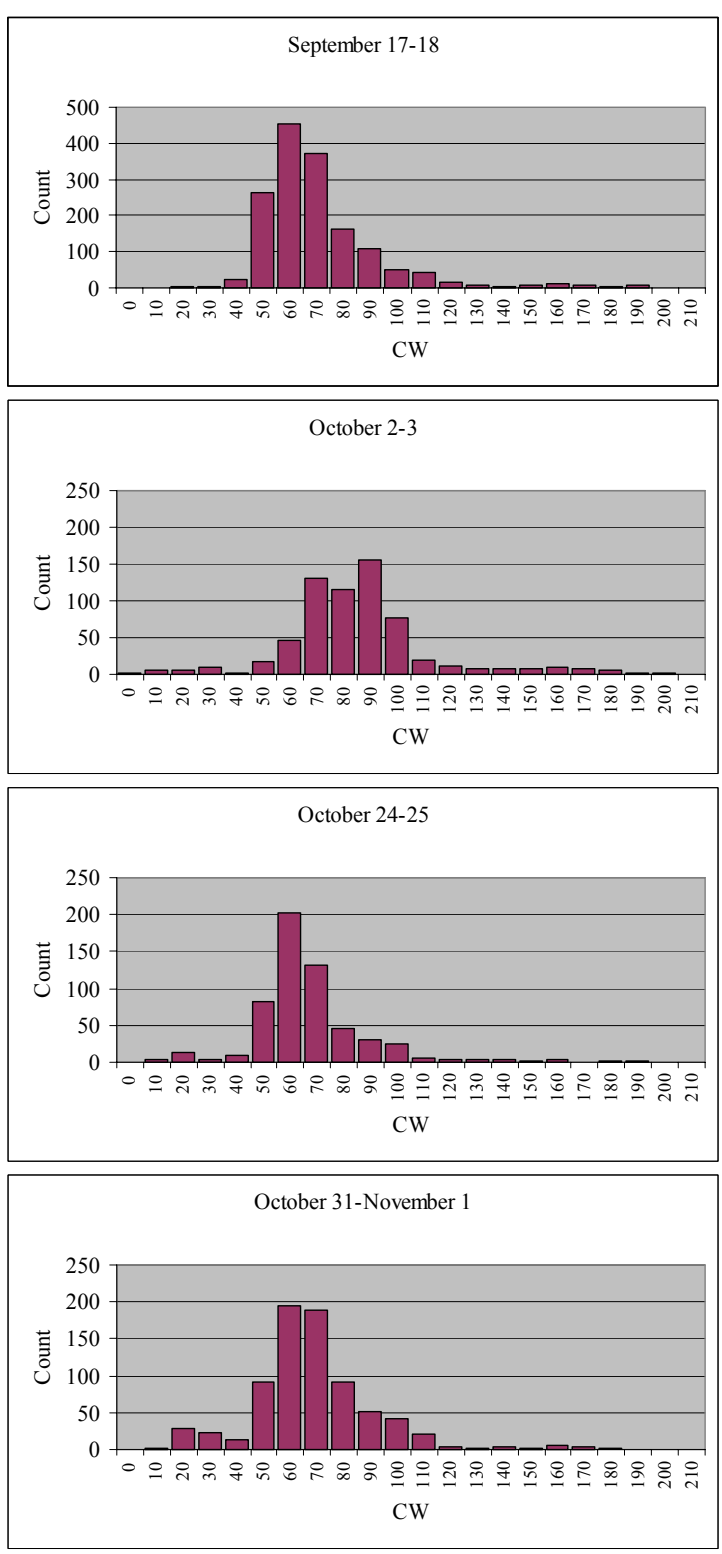

Figure 16. Size Frequency Distribution of Dungeness Crab Collected at all Sump Areas from July through Early November 2003 (carapace width in $\mathrm{mm}$ ). Note Y-axis scale 


\subsection{Tables}

Table 1. Coordinates of Proposed Alternative Sump Areas and Existing North Jetty Disposal Site. Projection is Oregon State Plane North Zone, NAD 27 Datum, Units in ft.

\begin{tabular}{|l|l|l|}
\hline Alternatives and Location & Northing & Easting \\
\hline Alternative 1 & & \\
\hline NW & 970157 & 1098763 \\
\hline NE & 971346 & 1100371 \\
\hline SE & 970542 & 1100966 \\
\hline SW & 969353 & 1099358 \\
\hline Alternative 2 & & \\
\hline NW & 968926 & 1096486 \\
\hline NE & 970115 & 1098094 \\
\hline SE & 969311 & 1098688 \\
\hline SW & 968122 & 1097080 \\
\hline Alternative 3 & & \\
\hline NW & 969685 & 1097812 \\
\hline NE & 970874 & 1099420 \\
\hline SE & 970070 & 1100015 \\
\hline SW & 968881 & 1098407 \\
\hline North Jetty Disposal Site & & \\
\hline W & 966681.51 & 1093345.54 \\
\hline N & 969765.57 & 1097251.09 \\
\hline E & 968978.46 & 1097867.90 \\
\hline S & 965894.40 & 1093932.35 \\
\hline
\end{tabular}

Table 2. Trip Dates and Corresponding Sampling Weeks, Indicating Neap and Spring Tide Series.

\begin{tabular}{|c|l|c|c|}
\hline Trip & \multicolumn{1}{|c|}{ Dates } & Week & Tide Series \\
\hline 1 & July 7-10 & 0 & Neap \\
\hline 2 & July 21-24 & 2 & Neap \\
\hline 3 & Aug 5-8 & 4 & Neap \\
\hline 4 & Aug 19-22 & 6 & Neap \\
\hline 5 & Sept 2-5 & 8 & Neap \\
\hline 6 & Sept 17-18 & 10 & Neap \\
\hline 7 & Oct 3-4 & 12 & Neap \\
\hline 8 & Oct 25-26 & 16 & Spring \\
\hline 9 & Nov 2-1 & 17 & Neap \\
\hline
\end{tabular}


Table 3. Trawl Depth (ft) Summary Statistics Associated With Each Sump Alternative Area

\begin{tabular}{|c|r|r|r|r|r|r|r|}
\hline Area & \multicolumn{1}{|c|}{ Mean } & \multicolumn{1}{c|}{ SD } & \multicolumn{1}{c|}{ Median } & \multicolumn{1}{c|}{$25 \%$-tile } & \multicolumn{1}{c|}{$75 \%$-tile } & \multicolumn{1}{c|}{$\min$} & \multicolumn{1}{c|}{$\max$} \\
\hline 1 & 30.53 & 1.52 & 30.65 & 29.65 & 31.55 & 26.25 & 33.00 \\
\hline 2 & 38.36 & 2.05 & 38.40 & 37.28 & 39.73 & 33.50 & 41.90 \\
\hline 3 & 33.43 & 1.52 & 33.50 & 32.10 & 35.05 & 30.60 & 35.95 \\
\hline
\end{tabular}

Table 4. Soft-Shell Crab (Numbers) Collected Over the Course of the Study Period

\begin{tabular}{|c|c|c|c|}
\hline Trip & Male & Female & Total \\
\hline 1 & & & \\
\hline 2 & & 2 & 2 \\
\hline 3 & 1 & 1 & 2 \\
\hline 4 & & 2 & 2 \\
\hline 5 & & & \\
\hline 6 & 2 & 3 & 5 \\
\hline 7 & & & \\
\hline 8 & 2 & 2 & 4 \\
\hline 9 & & & \\
\hline Total & 5 & 10 & 15 \\
\hline
\end{tabular}

Table 5. P-values of ANOVA Tests

\begin{tabular}{|l|r|r|r|r|}
\hline & \multicolumn{1}{|c|}{$\begin{array}{c}\text { Depth as } \\
\text { Covariate }\end{array}$} & $\begin{array}{c}\text { Area } x \text { Week } \\
\text { Interaction }\end{array}$ & \multicolumn{1}{|c|}{ Area } \\
\hline YOY-US & 0.866 & 0.017 & NA & NA \\
\hline YOY-M & 0.873 & 0.568 & 0.988 & 0.000 \\
\hline M1P & 0.100 & 0.68 & 0.065 & 0.000 \\
\hline M2P & 0.845 & 0.211 & 0.293 & 0.001 \\
\hline M3P & 0.176 & 0.185 & 0.679 & 0.000 \\
\hline TotM & 0.105 & 0.713 & 0.073 & 0.000 \\
\hline YOY-F & 0.972 & 0.046 & NA & NA \\
\hline F1P & 0.255 & 0.017 & NA & NA \\
\hline F2P & 0.856 & 0.024 & NA & NA \\
\hline F3P & 0.350 & 0.077 & 0.214 & 0.152 \\
\hline TotF & 0.303 & 0.158 & 0.059 & 0.000 \\
\hline Total-C & 0.134 & 0.341 & 0.041 & 0.000 \\
\hline
\end{tabular}

Yellow Cells Highlight Values with $p<0.05$.

Green Cells Highlight Values with $p<0.10$. 
Table 6. Post-Hoc Power Analysis

\begin{tabular}{|l|c|c|c|c|}
\hline & $\begin{array}{c}\text { Observed Total } \\
\text { Density } \\
\text { (crab/ha) }\end{array}$ & $\begin{array}{c}\text { Significance } \\
\text { Level }\end{array}$ & $\begin{array}{c}\text { Detectable } \\
\text { Difference } \\
\text { (crab/ha) }\end{array}$ & Power \\
\hline Total Male & 338 & 0.05 & 147 & $57 \%$ \\
\hline Total Female & 252 & 0.05 & 160 & $96 \%$ \\
\hline All Crab & 601 & 0.05 & 313 & $86 \%$ \\
\hline
\end{tabular}

Table 7. Fish Taxa in Rank Order of Abundance, Including Mean Density (Fish/ha), Mean Size ( $\mathrm{TL}=$ Total Length in $\mathrm{mm}$ ), and Size Range.

\begin{tabular}{|c|c|c|c|c|c|}
\hline Common Name & Scientific name / Family & Total \# & $\begin{array}{c}\text { Mean } \\
\text { Density } \\
\text { (fish / ha) }\end{array}$ & $\begin{array}{c}\text { Size } \\
\text { Range } \\
(\mathrm{mm} \text { TL) }\end{array}$ & $\begin{array}{c}\text { Mean } \\
\text { Size } \\
(\mathrm{mm} \mathrm{TL})\end{array}$ \\
\hline Pacific tomcod & Microgadus proximus & 5333 & 719.16 & $30-270$ & 137 \\
\hline Whitebait Smelt & Allosmerus elongatus & 1834 & 247.32 & $30-145$ & 104 \\
\hline Northern Anchovy & Engraulis mordax & 976 & 131.61 & $45-170$ & 105 \\
\hline Staghorn sculpin & Leptocottus armatus & 858 & 115.70 & $25-275$ & 138 \\
\hline English Sole & Pleuronectes vetulus & 807 & 108.82 & $30-465$ & 125 \\
\hline Shiner Surfperch & Cymatogaster aggregata & 497 & 67.02 & $30-155$ & 92 \\
\hline Larval Smelt & Osmeridae & 375 & 50.57 & $35-60$ & 48 \\
\hline Longfin Smelt & Spirinchus thaleichthys & 308 & 41.53 & $60-155$ & 111 \\
\hline Starry Flounder & Platichthys stellatus & 134 & 18.07 & $65-490$ & 199 \\
\hline Larval Flatfish & Pleuronectidae & 131 & 17.67 & $25-80$ & 34 \\
\hline Warty Poacher & Occella verrucosa & 90 & 12.14 & $26-150$ & 69 \\
\hline Other/UID Smelt spp. & Osmeridae & 49 & 6.61 & $30-140$ & 89 \\
\hline Saddleback Gunnel & Pholis ornata & 44 & 5.93 & $75-250$ & 138 \\
\hline Butter Sole & Isopsetta isolepis & 30 & 4.05 & $55-100$ & 76 \\
\hline Skate & Rajidae & 22 & 2.97 & $175-1018$ & \\
\hline Pacific Sanddab & Citharichthys sordidus & 16 & 2.16 & $100-375$ & 242 \\
\hline Snake Prickleback & Lumpenus sagitta & 16 & 2.16 & $50-310$ & 184 \\
\hline Sand Sole & Psettichthys melanosticus & 14 & 1.89 & $80-445$ & 299 \\
\hline Snailfish spp. & Liparidae & 12 & 1.62 & $9-180$ & 61 \\
\hline Pacific Herring & Clupea harengus & 6 & 0.81 & $90-170$ & 128 \\
\hline Poacher sp. & Agonidae & 5 & 0.67 & $57-118$ & 88 \\
\hline UID Flatfish spp. & Pleuronectidae & 4 & 0.54 & & \\
\hline Sculpin spp. & Cottidae & 3 & 0.40 & $48-95$ & 213 \\
\hline Redtail Surfperch & Amphistichus rhodoterus & 3 & 0.40 & $90-110$ & 98 \\
\hline Pipefish & Syngnathus leptorhynchus & 3 & 0.40 & $110-200$ & 145 \\
\hline Pacific Sandlance & Ammodytes hexapterus & 2 & 0.27 & $100-140$ & 120 \\
\hline Pacific Sandfish & Trichodon trichodon & 2 & 0.27 & $90-185$ & 137 \\
\hline UID postlarval fishes & UID & 2 & 0.27 & & \\
\hline Cabezon & Scorpaenichthys marmoratus & 1 & 0.13 & 105 & 105 \\
\hline Pile Surfperch & Damalichthys vacca & 1 & 0.13 & 105 & 105 \\
\hline Lingcod & Ophiodon elongatus & 1 & 0.13 & 160 & 160 \\
\hline Number groups & & 31 & & & \\
\hline Number taxa (bold) & & 26 & & & \\
\hline
\end{tabular}


Table 8. Fish Diversity and Mean Density by Area

\begin{tabular}{|c|c|c|c|c|}
\hline Area & $\begin{array}{c}\text { Total \# of Fish } \\
\text { Species }\end{array}$ & $\begin{array}{c}\text { Total \# Fish } \\
\text { Collected }\end{array}$ & $\begin{array}{c}\text { Area Sampled } \\
\left(\mathrm{m}^{2}\right)\end{array}$ & $\begin{array}{c}\text { Mean Density } \\
(\text { fish / ha })\end{array}$ \\
\hline 1 & 25 & 3437 & 24097.59 & 1426.28 \\
\hline 2 & 21 & 5150 & 25368.54 & 2030.07 \\
\hline 3 & 20 & 2992 & 24689.79 & 1211.84 \\
\hline
\end{tabular}

Table 9. Numerically Dominant Fish Species by Area

\begin{tabular}{|c|c|c|c|}
\hline Rank & Common name & Count & $\begin{array}{l}\text { Mean Density } \\
\text { (fish / ha) }\end{array}$ \\
\hline \multicolumn{4}{|l|}{ Area 1} \\
\hline 1 & Pacific tomcod & 1449 & 601.31 \\
\hline 2 & Northern Anchovy* & 619 & 256.87 \\
\hline 3 & English Sole & 362 & 150.22 \\
\hline 4 & Larval Smelt & 253 & 104.99 \\
\hline 5 & Staghorn sculpin & 235 & 97.52 \\
\hline 6 & Shiner Surfperch & 223 & 92.54 \\
\hline 7 & Larval Flatfish & 84 & 34.86 \\
\hline 8 & Starry Flounder & 52 & 21.58 \\
\hline 9 & Whitebait Smelt & 50 & 20.75 \\
\hline 10 & Longfin Smelt & 30 & 12.45 \\
\hline \multicolumn{4}{|l|}{ Area 2} \\
\hline 1 & Pacific tomcod & 2416 & 952.36 \\
\hline 2 & Whitebait Smelt & 1432 & 564.48 \\
\hline 3 & Staghorn sculpin & 345 & 136.00 \\
\hline 4 & Northern Anchovy & 242 & 95.39 \\
\hline 5 & Longfin Smelt & 173 & 68.19 \\
\hline 6 & English Sole & 167 & 65.83 \\
\hline 7 & Larval Smelt & 94 & 37.05 \\
\hline 8 & Warty Poacher & 67 & 26.41 \\
\hline 9 & Shiner Surfperch & 52 & 20.50 \\
\hline 10 & Larval Flatfish & 36 & 14.19 \\
\hline \multicolumn{4}{|l|}{ Area 3} \\
\hline 1 & Pacific tomcod & 1468 & 594.58 \\
\hline 2 & Whitebait Smelt & 352 & 142.57 \\
\hline 3 & Staghorn sculpin & 278 & 112.60 \\
\hline 4 & English Sole & 278 & 112.60 \\
\hline 5 & Shiner Surfperch & 222 & 89.92 \\
\hline 6 & Northern Anchovy & 115 & 46.58 \\
\hline 7 & Longfin Smelt & 105 & 42.53 \\
\hline 8 & Starry Flounder & 50 & 20.25 \\
\hline 9 & Larval Smelt & 28 & 11.34 \\
\hline 10 & Saddleback Gunnel & 16 & 6.48 \\
\hline
\end{tabular}

*large catch of 500 Northern Anchovy on September 4, 2003 
Table 10. Annual Variability of Mean $1+$ Crab Densities (crab/ha) from All Habitats in Four West Coast Estuaries (Rooper et al., 2002)

\begin{tabular}{|l|c|c|}
\hline \multicolumn{1}{|c|}{ Estuary } & Low & High \\
\hline Gray Harbor & 236 & 1,719 \\
\hline Willapa Bay & 308 & 1,087 \\
\hline Yaquina Bay & 324 & 884 \\
\hline Coos Bay & 435 & 1,417 \\
\hline
\end{tabular}




\section{Appendix A: Length Frequency Graphs of Most Abundant Fish Species}



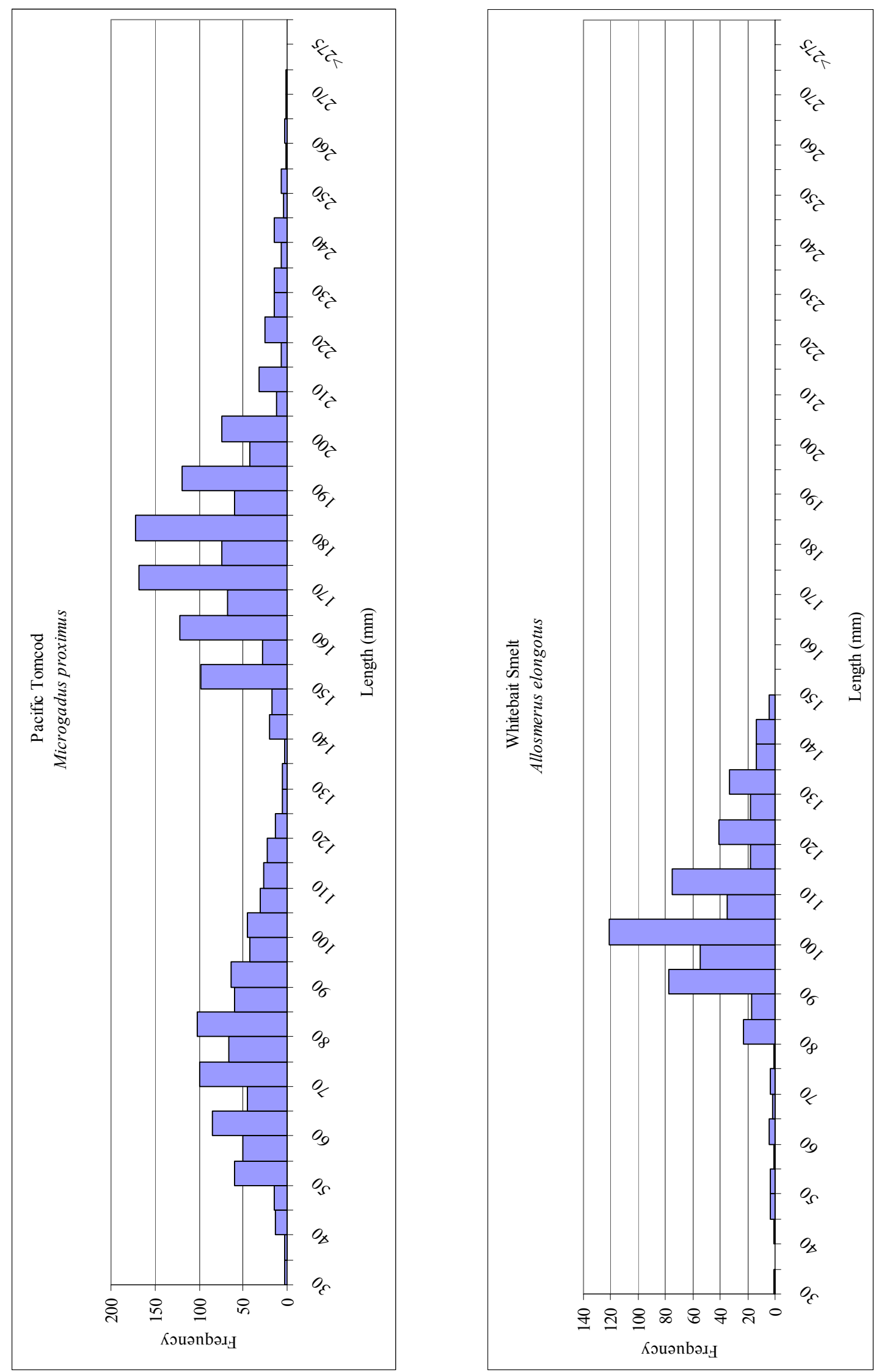

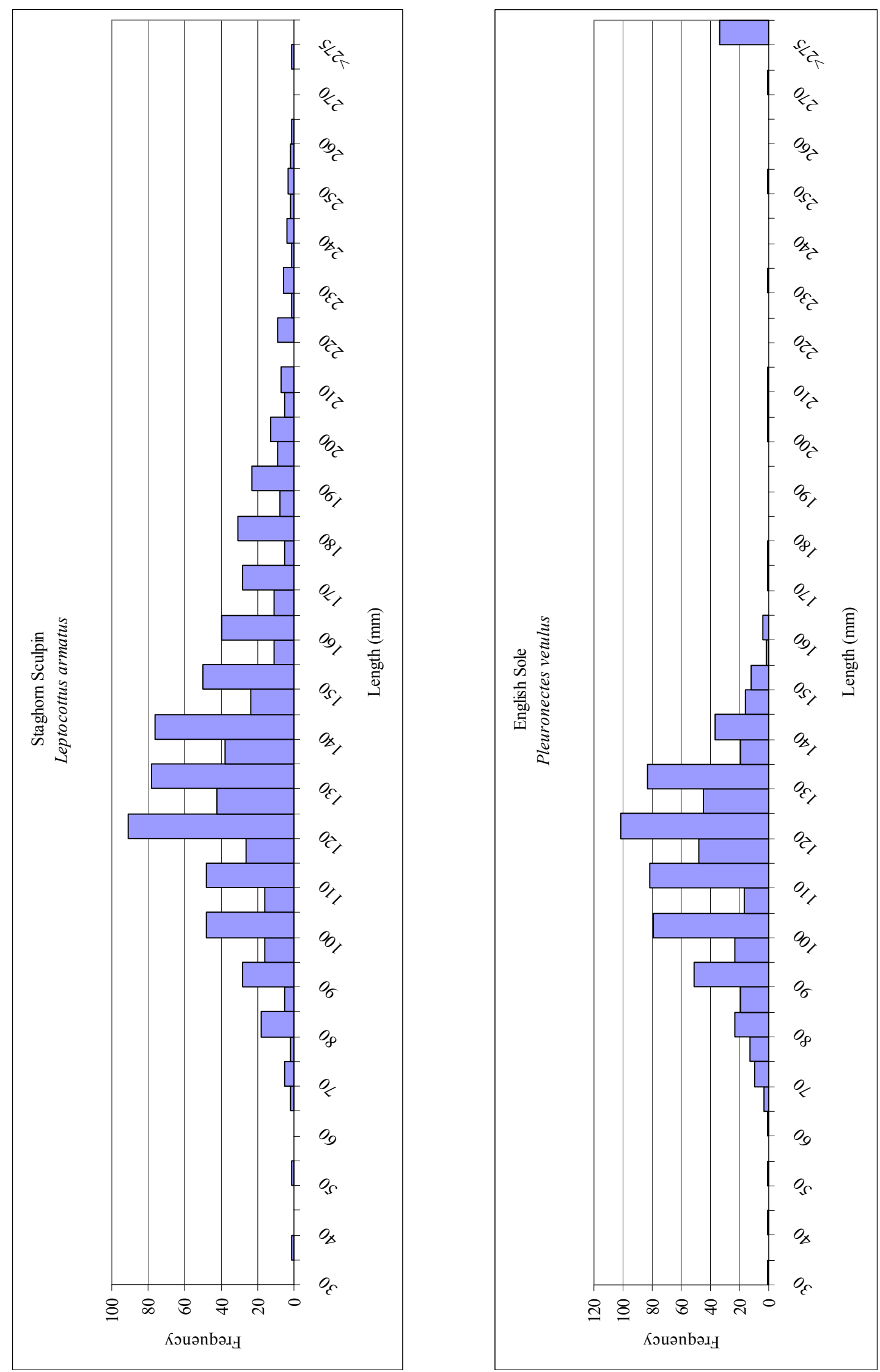

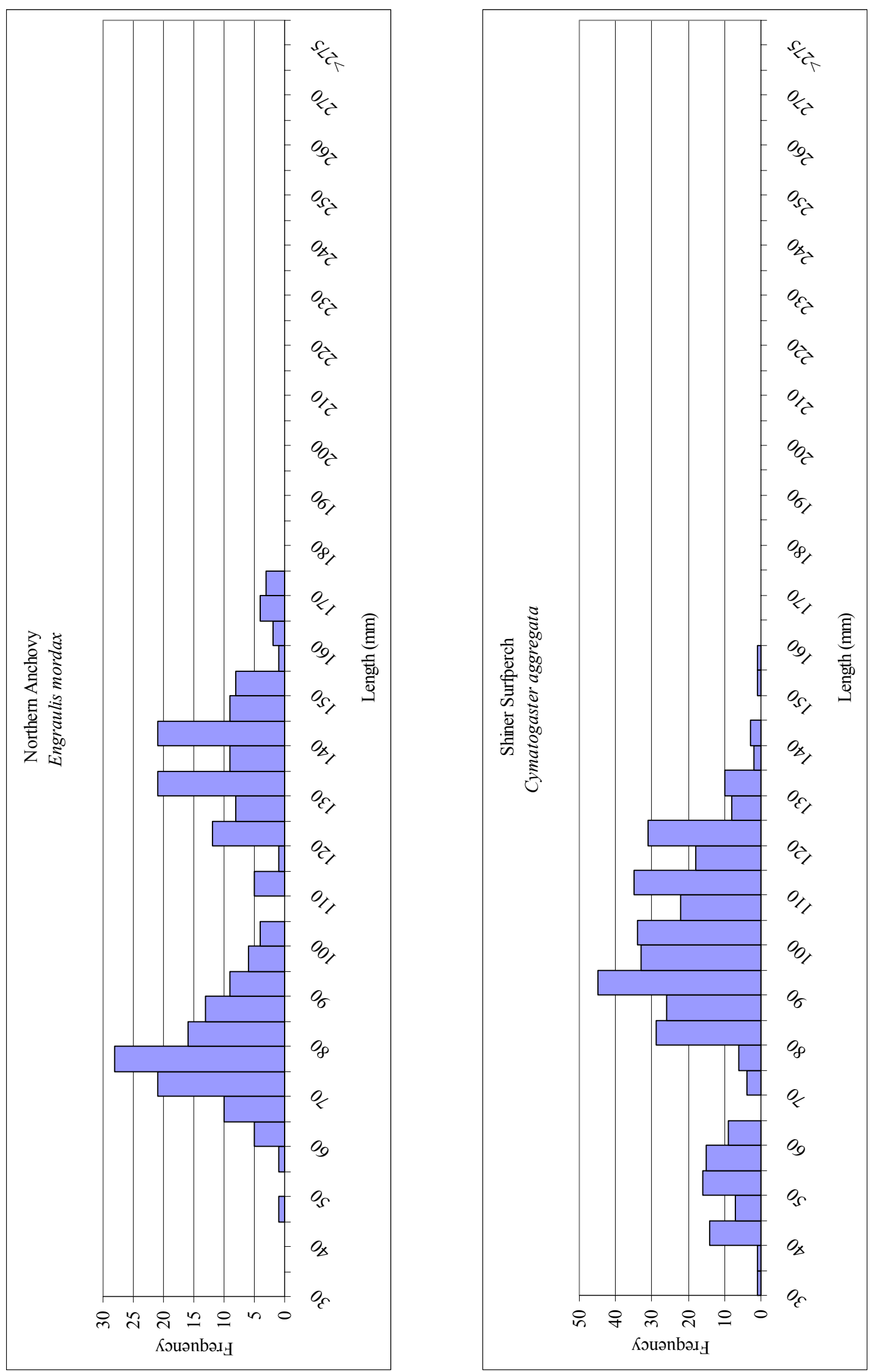

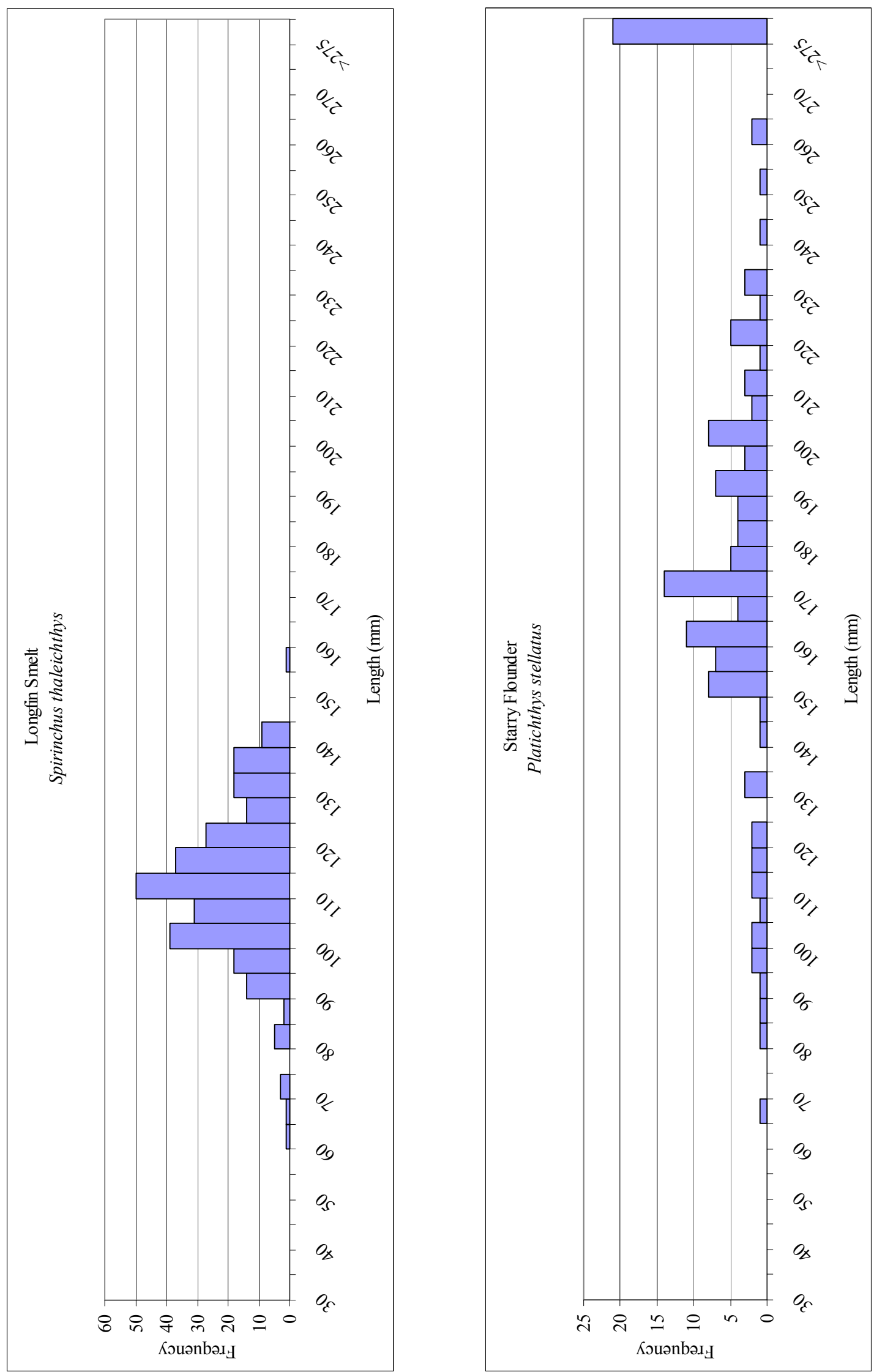


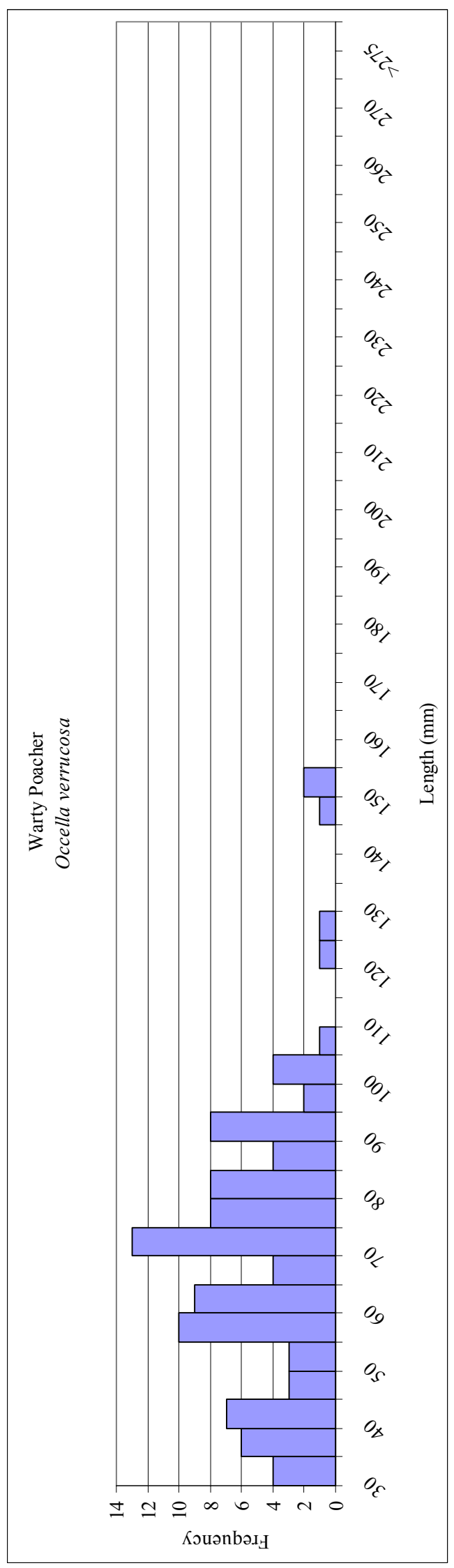




\section{DISTRIBUTION}

No. of

Copies

\section{OFFSITE}

$6 \quad$ U.S. Army Corps of Engineers, Portland District

Kim Larson (3)

Doris McKillip (3)

\section{ONSITE}

3 Battelle Marine Sciences Laboratory

Gregory D. Williams MSLTRL1/1

Walter H. Pearson $\quad$ MSL5/304

Nathan R. Evans MSLTRL1/13

1 Pacific Northwest National Laboratory

Information Release K1-06 